\title{
Idaho National Laboratory's Greenhouse Gas FY08 Baseline
}

\author{
Jennifer D. Morton
}

September 2010

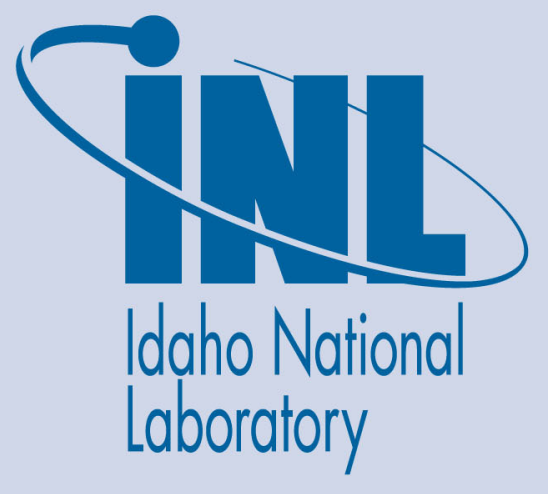

The INL is a U.S. Department of Energy National Laboratory operated by Battelle Energy Alliance 


\section{DISCLAIMER}

This information was prepared as an account of work sponsored by an agency of the U.S. Government. Neither the U.S. Government nor any agency thereof, nor any of their employees, makes any warranty, expressed or implied, or assumes any legal liability or responsibility for the accuracy, completeness, or usefulness, of any information, apparatus, product, or process disclosed, or represents that its use would not infringe privately owned rights. References herein to any specific commercial product, process, or service by trade name, trade mark, manufacturer, or otherwise, does not necessarily constitute or imply its endorsement, recommendation, or favoring by the U.S. Government or any agency thereof. The views and opinions of authors expressed herein do not necessarily state or reflect those of the U.S. Government or any agency thereof. 


\title{
Idaho National Laboratory's Greenhouse Gas FY08 Baseline
}

\author{
Jennifer D. Morton
}

September 2010

Idaho National Laboratory Idaho Falls, Idaho 83415

http://www.inl.gov

Prepared for the

U.S. Department of Energy

Office of Nuclear Energy

Under DOE Idaho Operations Office

Contract DE-AC07-05ID14517 



\section{EXECUTIVE SUMMARY}

A greenhouse gas $(\mathrm{GHG})$ inventory is a systematic attempt to account for the production and release of certain gasses generated by an institution from various emission sources. The gasses of interest are those which have become identified by climate science as related to anthropogenic global climate change. This document presents an inventory of GHGs generated during fiscal year (FY) 2008 by Idaho National Laboratory (INL), a Department of Energy (DOE)-sponsored entity, located in southeastern Idaho.

Concern about the environmental impact of GHGs has grown in recent years. This, together with a desire to decrease harmful environmental impacts, would be enough to encourage the calculation of a baseline estimate of total GHGs generated at INL. Additionally, INL has a desire to see how its emissions compare with similar institutions, including other DOE-sponsored national laboratories. Executive Order 13514 requires that federally-sponsored agencies and institutions document reductions in GHG emissions in the future, and such documentation will require knowledge of a baseline against which reductions can be measured.

INL's FY08 GHG inventory was calculated according to methodologies identified in federal recommendations and an as-yet-unpublished Technical and Support Document (TSD) using operational control boundaries. It measures emissions generated in three Scopes: (1) INL emissions produced directly by stationary or mobile combustion and by fugitive emissions, (2) the share of emissions generated by entities from which INL purchased electrical power, and (3) indirect or shared emissions generated by outsourced activities that benefit INL (occur outside INL's organizational boundaries but are a consequence of INL's activities).

This inventory found that INL generated a total of 114,256 MT of $\mathrm{CO}_{2}$-equivalent emissions during FY08. The following conclusions were made from looking at the results of the individual contributors to INL's baseline GHG inventory:

- Electricity is the largest contributor to INL's GHG inventory, with over 50\% of the net anthropogenic $\mathrm{CO}_{2}$ e emissions

- Other sources with high emissions were stationary combustion, fugitive emissions from the onsite landfill, mobile combustion (fleet fuels) and the employee commute

- Sources with low emissions were contracted waste disposal, wastewater treatment (onsite and contracted) and fugitive emissions from refrigerants.

This report details the methods behind quantifying INL's GHG inventory and discusses lessons learned on better practices by which information important to tracking GHGs can be tracked and recorded. It is important to stress that the methodology behind this inventory followed guidelines that have not yet been formally adopted. Thus, some modification of the conclusions may be necessary as additional guidance is received. Further, because this report differentiates between those portions of INL that are managed and operated by the Battelle Energy Alliance (BEA) and those managed by other contractors, it includes only that large proportion of Laboratory activities overseen by BEA. It is assumed that other contractors will provide similar reporting for those activities they manage, where appropriate. 


\section{ACKNOWLEDGMENTS}

The author would like to extend recognition to the following individuals for their thoughtful review of this document and/or calculations:

- Ernest Fossum, Sustainable INL Energy Manager

- Barney Hadden and Heather Rohrbaugh, INL Tech Editing

- Chris Ischay, Sustainable INL Program Manager

- Michael Reed, INL's Advanced Process \& Decision Systems Department

- Joshua Skov and Aaron Toneys, Good Company, www.goodcompany.com. 


\section{CONTENTS}

EXECUTIVE SUMMARY

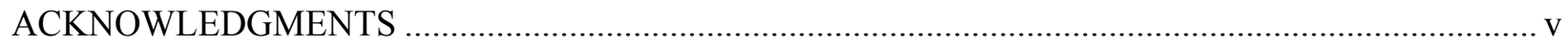

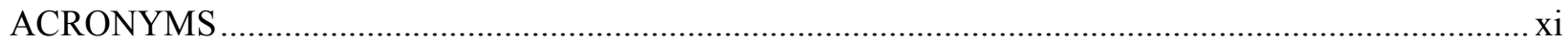

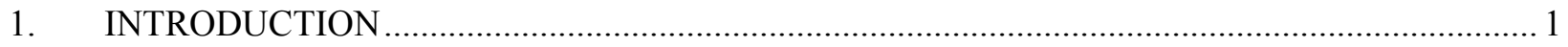

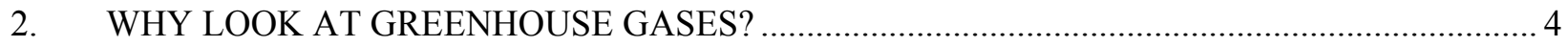

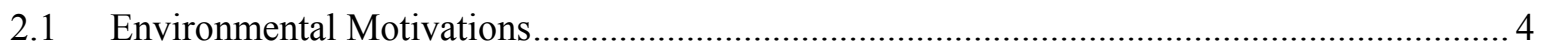

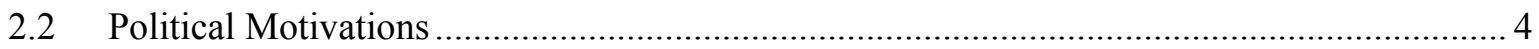

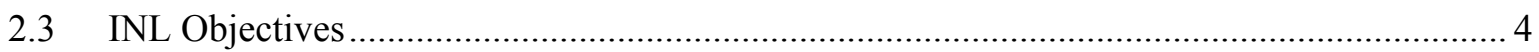

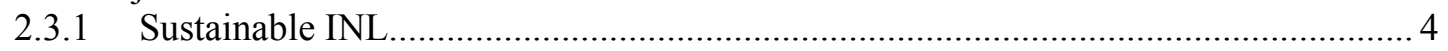

3. APPROACH TO ESTABLISHING INL'S GHG BASELINE ................................................. 6

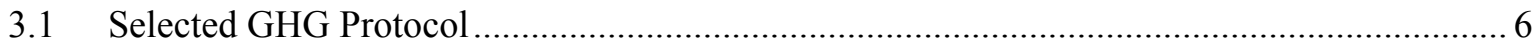

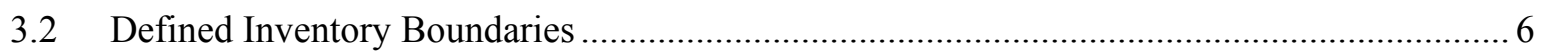

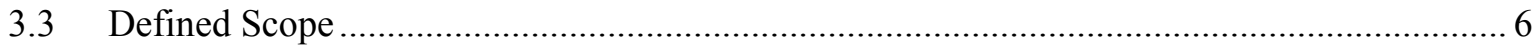

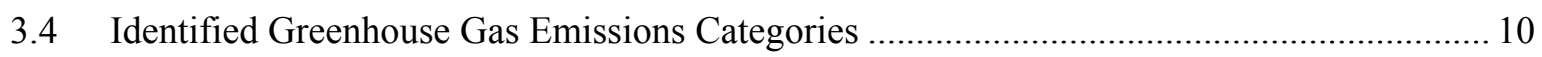

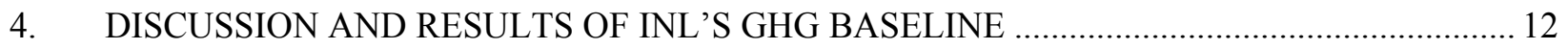

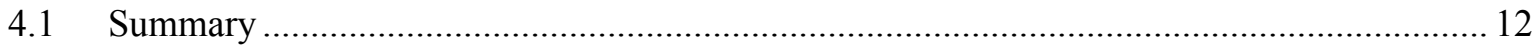

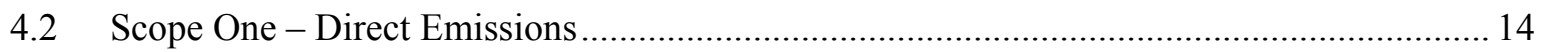

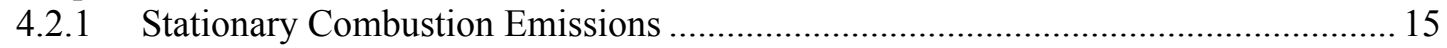

4.2.2 Mobile Combustion Emissions ............................................................................ 16

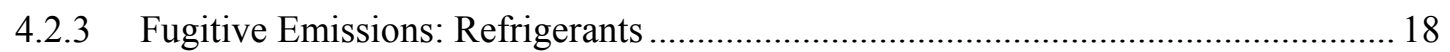

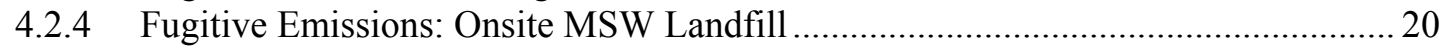

4.2.5 Fugitive Emissions: Onsite Wastewater Treatment ……....................................... 22

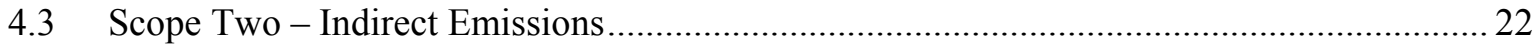

4.3.1 Purchased Electricity and Renewable Energy Certificates Emissions ...................... 23

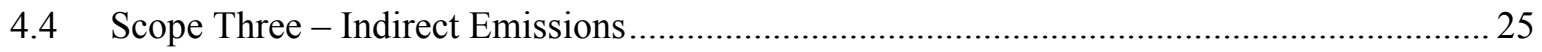

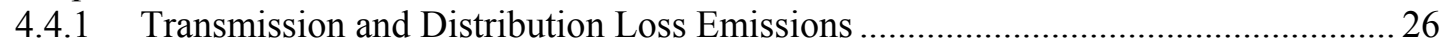

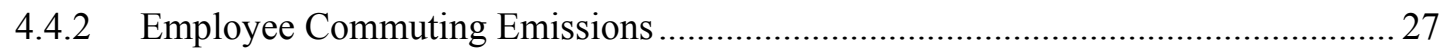

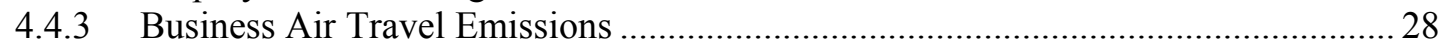

4.4.4 Business Ground Travel: Rental Vehicle Emissions .............................................. 29

4.4.5 Business Ground Travel: Personal Vehicle Emissions ............................................ 30

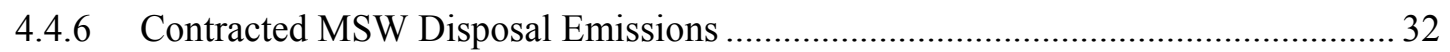

4.4.7 Contracted Wastewater Treatment ........................................................................ 33

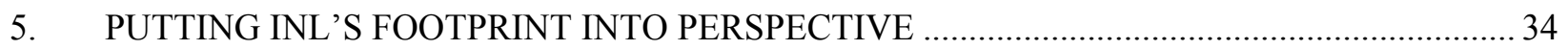

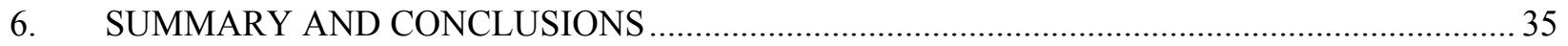

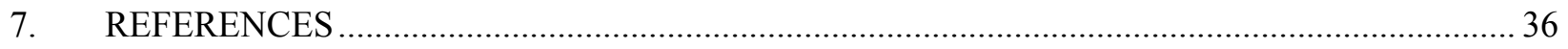

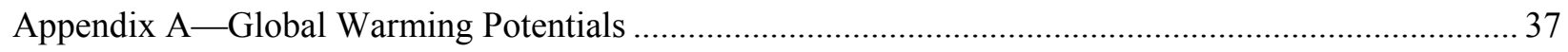




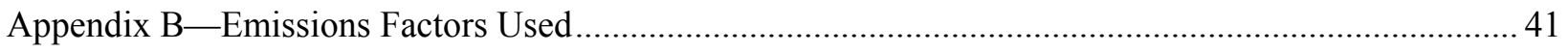

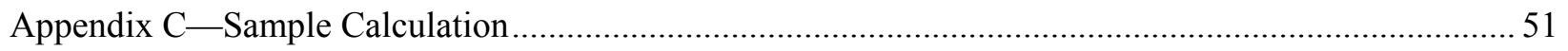

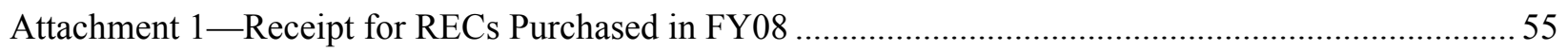

\section{FIGURES}

Figure 1. Location map of the INL Site and major facilities. ..........................................................

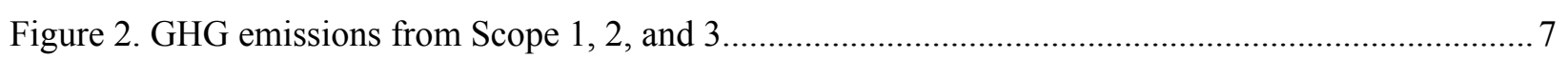

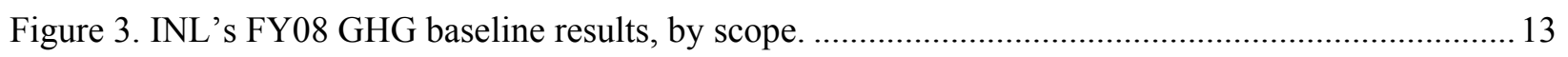

Figure 4. INL's FY08 GHG baseline results, from largest to smallest emissions category,

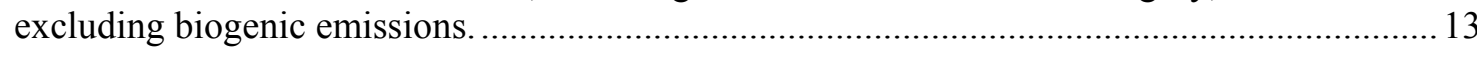

Figure 5. INL's FY08 GHG baseline results, by scope and emissions category, excluding

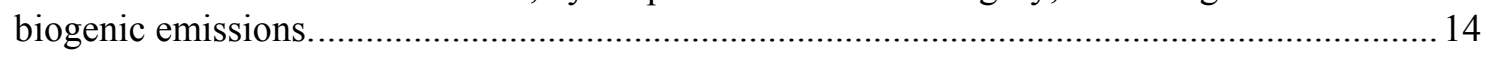

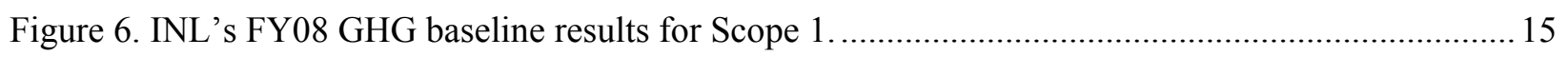

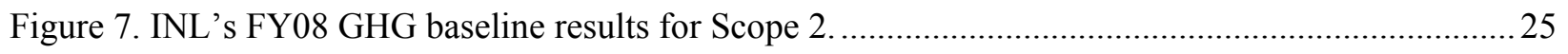

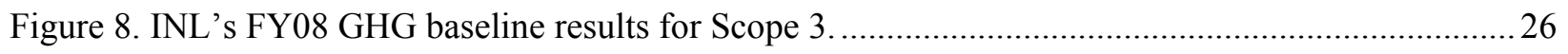

Figure 9. Number of miles traveled for sampled business travel in personally owned vehicles. ............... 31

Figure 10. Miles traveled by number of trips in the sampled group. ......................................................... 31

\section{TABLES}

Table 1. GHG emissions categories identified in Guidance and TSD ................................................ 8

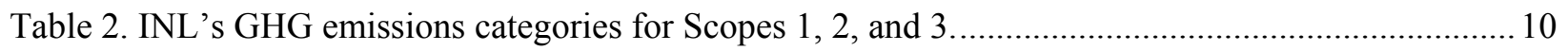

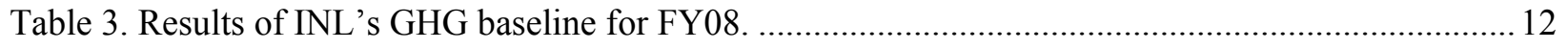

Table 4. Amounts of fuel used for stationary combustion at INL during FY08..................................... 15

Table 5. Amounts of fossil fuels used for mobile combustion at INL during FY08. .............................. 17

Table 6. Amounts of biofuels used for mobile combustion at INL during FY08................................... 17

Table 7. Fugitive refrigerants evaluated for GHG emissions during FY08 at INL ................................ 19

Table 8. Amount of MSW produced by INL during FY08 for disposal in onsite CFA landfill................21

Table 9. FY08 population data by facility for onsite wastewater treatment calculations. .......................22

Table 10. INL's FY08 electrical purchases by location and provider. ....................................................23

Table 11. INL's GHG emissions from electricity purchased in FY08 .....................................................24

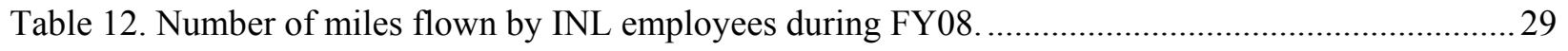

Table 13. Number of miles flown by INL employees during FY08..................................................... 30

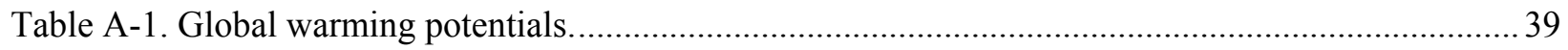

Table B-1. Stationary combustion conversion and emissions factors used. …........................................ 43 
Table B-2. Mobile combustion emissions factors used.

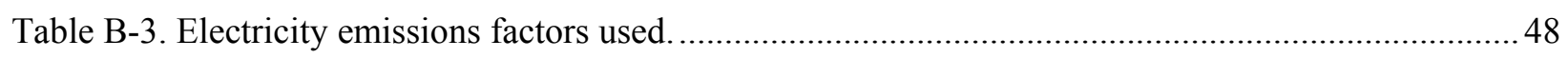

Table B-4. Employee commute, rental car miles, and personal car miles emissions factors used. ........... 49

Table B-5. Business travel airline miles emissions factors used. .......................................................... 49 


\section{ACRONYMS}

AMWTP Advanced Mixed Waste Treatment Project

ATR Advanced Test Reactor

BBWI Bechtel BWXT Idaho, LLC

BEA Battelle Energy Alliance

CFA Central Facilities Area

CAS Chemical Abstract Service

CEQ Council on Environmental Quality

CITRC Critical Infrastructure Test Range Complex

CNG Compressed Natural Gas

$\mathrm{CO}_{2} \quad$ carbon dioxide

$\mathrm{CO}_{2} \mathrm{e} \quad \mathrm{CO}_{2}$ equivalents

CWI CH2M-WG Idaho, LLC

DOE Department of Energy

DOE-HQ Department of Energy Headquarters

DOE-ID Department of Energy Idaho Operations Office

eGRID Emissions \& Generation Resource Integrated Database

EIA Energy Information Administration

EO executive order

EPA Environmental Protection Agency

FAST Federal Automated Statistical Tool

FEMP Federal Energy Management Program

FERC Federal Energy Regulatory Commission

FY fiscal year

GHG greenhouse gas

GSA General Services Administration

GWP Global Warming Potential

HHV higher heating value

ICP Idaho Cleanup Project

INEEL Idaho National Engineering and Environmental Laboratory (a forerunner of INL)

INL Idaho National Laboratory

INTEC Idaho Nuclear Technology Center

INWMIS INEEL Nonradiological Waste Management Information System

IWTS Integrated Waste Tracking System 


$\begin{array}{ll}\text { LMI } & \text { Land Management Institute } \\ \text { LNG } & \text { Liquefied Natural Gas } \\ \text { LPG } & \text { Liquefied Propane Gas } \\ \text { MFC } & \text { Materials and Fuels Complex } \\ \text { MRR } & \text { Mandatory Reporting of Greenhouse Gases Rule } \\ \text { MSW } & \text { municipal solid waste } \\ \text { MT } & \text { metric tonnes } \\ \text { NRF } & \text { Naval Reactors Facility } \\ \text { NWPP } & \text { Northwest Power Pool } \\ \text { ODS } & \text { ozone-depleting substance } \\ \text { PNR } & \text { Passenger Name Record } \\ \text { PSS } & \text { Public Sector Standard } \\ \text { RECs } & \text { Renewable Energy Certificates } \\ \text { SMC } & \text { Specific Manufacturing Capability } \\ \text { T\&D } & \text { Transmission \& Distribution } \\ \text { TSD } & \text { Technical Support Document } \\ \text { WRI } & \text { World Resource Institute }\end{array}$




\section{Idaho National Laboratory's Greenhouse Gas FY08 Baseline}

\section{INTRODUCTION}

The Department of Energy (DOE) Idaho National Laboratory (INL) has been in operation since 1949. Battelle Energy Alliance (BEA) currently operates INL for DOE. In addition to specializing in nuclear energy, INL supports the overall DOE missions in energy research, science, and national defense as indicated in their stated mission to "Ensure the nation's energy security with safe, competitive, and sustainable energy systems and unique national and homeland security capabilities."

The INL Site covers approximately 890 square miles of high-elevation desert in southeastern Idaho and is home to multiple facilities operated by several contractors in addition to BEA. BEA is currently the largest contractor and is responsible for day-to-day management and operation of the laboratory. Other major contractors currently operating at the INL Site include:

- $\mathrm{CH} 2 \mathrm{M}$ WG Idaho manages the Idaho Cleanup Project (ICP), which includes the Idaho Nuclear Technology Center (INTEC) facility and the performance of cleanup work across the INL Site

- Bechtel BWXT Idaho operates the Advanced Mixed Waste Treatment Project (AMWTP)

- Bechtel Bettis operates the Naval Reactor Facilities (NRF)

- DOE Idaho Operations Office (DOE-ID).

This report will look exclusively at the greenhouse gas emissions that INL (BEA) owns and it is assumed that other contractors will provide similar reporting for the activities they control. All attempts have been made to look only at INL's emissions unless indicated otherwise. In this report "INL" is used to indicate the BEA operations and employees to which this report applies, while "INL Site" will apply to the entire geographical area and all contractors.

INL's employees work at multiple locations throughout the INL Site as indicated in Figure 1. The metropolitan area closest to the Site is Idaho Falls, which is also the location of the Research and Education Campus or "town" facilities. The major campuses within the INL Site where INL employees work include the Advanced Test Reactor (ATR) Complex (45 miles west of Idaho Falls), Materials and Fuels Complex (MFC, 28 miles west of Idaho Falls), and the Specific Manufacturing Capability (SMC, 60 miles northwest of Idaho Falls). The INL Site's large geographical area and long history make for some unique characteristics, including:

- Long Commutes. Approximately half of INL's employees work at Site desert locations, approximately 30 to 50 miles west of Idaho Falls, and ride INL buses or utilize their own personal vehicles to commute to work.

- Large Transportation Fleet. INL operates a large vehicle fleet that includes light-duty passenger vehicles, commercial buses, and off-road equipment. This fleet is being modernized through a transition to General Services Administration (GSA) vehicles. INL's commercial buses are used for transporting employees from all INL Site contractors on their commute to and from the Site facilities.

- Antiquated Facilities. The INL Site includes hundreds of buildings, some of which are DOE-owned, some leased; however, many of these buildings are aged. INL is in the process of modernizing its buildings to support the INL mission, attract and retain its work-force, and satisfy executive order (EO) requirements. 


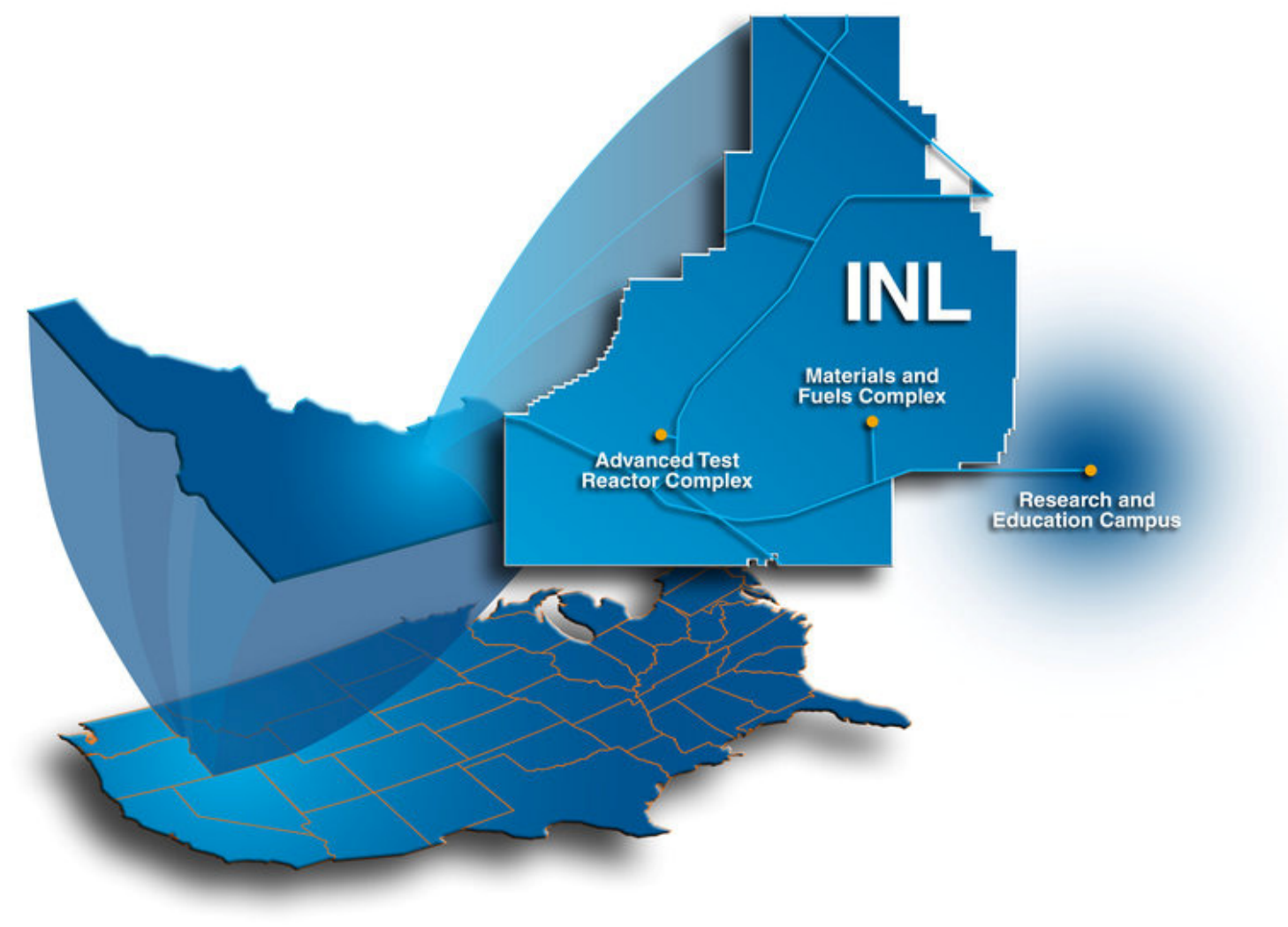

Figure 1. Location map of the INL Site and major facilities.

On a historical note, INL is home to the peaceful atom - the world's first usable amount of electricity produced from nuclear energy was generated at INL's forerunner, the National Reactor Test Station, in 1951. With such a long history and a commitment to revitalizing nuclear energy, a low-carbon source of energy, it is only appropriate that INL would be interested in lowering its own GHG emissions. The first step to quantifying any greenhouse gas savings is to establish a baseline, and the intent of this report is to document that effort. Fiscal year (FY) 2008 was chosen as the baseline year since this calculation effort will also support Executive Order (EO) 13514, "Federal Leadership in Environmental, Energy, and Economic Performance," requirements to report on and reduce greenhouse gas emissions based on an FY08 baseline.

This report documents the methodology and calculations and provides perspective on the results of INL's baseline greenhouse gas inventory (also referred to as the GHG or carbon footprint). Methodology is still being developed for calculating GHGs, particularly at the federal level where the intent is to standardize the emissions categories considered and the associated calculations to standardize reporting. These baseline calculations follow the most current methodology available: the EO 13514 DRAFT "Federal Greenhouse Accounting and Reporting Guidance" (referred to herein as the Guidance) [2010], and its accompanying DRAFT "Federal Greenhouse Accounting and Reporting Guidance: Technical Support Document" (referred to herein as the TSD) [2010]. As of the printing of this report the Guidance and TSD are still in draft format as they were submitted to the Council on Environmental Quality (CEQ) in April of 2010 and are currently undergoing review and approval. In addition to standardizing the methodology, these documents attempt to best utilize the data that federal facilities are already required to report, such as fuel (for energy and fleet) and electricity usage. The Guidance and TSD utilize a combination of existing guidance and regulations as their basis, including: 
- The World Resource Institute's (WRI's) and Land Management Institute's (LMI's) Public Sector GHG Accounting and Reporting Standard (Public Sector Standard or PSS)

- Environmental Protection Agency's (EPA's) Climate Leaders Guidance

- EPA's “Final Rule: Mandatory Reporting of Greenhouse Gases” (MRR, 74 FR 56260), as references for their methodologies and emission factors.

In addition to reviews performed by key INL personnel (Chris Ischay and Ernest Fossum from Sustainable INL), this report was reviewed externally by industry experts Joshua Skov and Aaron Toneys. Skov and Toneys, both of Good Company in Eugene, Oregon, are experienced in performing GHG inventories for private industry, academia, and government entities (federal, state, and local), and in determining the carbon impact of new development projects including transportation infrastructure and alternative energy facilities. 


\section{WHY LOOK AT GREENHOUSE GASES?}

INL has many reasons to calculate the organization's greenhouse gas emissions, including environmental and political pressures external to INL as well as internal desires within the Laboratory.

When considering the results of this analysis, it will be important to consider the limits of the analysis. While a GHG inventory is currently the popular method for assessing an organization's environmental impacts, it is focused on just one impact to the earth: climate change. It is important to keep the full lifecycle effects of various sources of environmental impact — including air pollution, habitat degradation, and resource extraction — in mind when making a decision or drawing any overall conclusions.

\subsection{Environmental Motivations}

Environmental impacts come in a variety of forms. Many emitted pollutants have been the subject of historical environmental regulation (e.g., air pollutants by the Clean Air Act of 1963 or water pollutants by the Federal Water Pollution Control Amendments of 1972). Climate change (sometimes called global warming) is a primary focus of current scientific inquiry, and policymaking reflects the current understanding of the impact of GHGs in causing anthropogenic climate change. Policies currently being considered include the introduction of carbon taxes or carbon-emissions trading, a market-based system of incentives aimed at achieving reductions in emissions of GHGs. Such a system might bear similarity to the trading system in place in the United States that regulates $\mathrm{SO}_{2}$ emissions under the Clean Air Act of 1990.

\subsection{Political Motivations}

This effort of identifying and calculating GHG emissions supports Executive Order 13514, "Federal Leadership in Environmental, Energy, and Economic Performance." As the name indicates, the EO requires that federal agencies "lead by example" in measuring, reporting, and reducing GHG emissions. It requires that agencies of the federal government report existing emissions and the steps taken to eliminate pollutants in a way that is transparent.

This report represents the effort to catalog INL's contribution to the INL Site carbon footprint. For purposes of compliance to the EO, some emission metrics must be separated from information that INL already tracks and reports for the entire Site (e.g., fuels and electricity), and several new metrics, such as employee commuting and travel, are new and have not been previously tracked.

\subsection{INL Objectives}

INL chooses to support efforts to monitor and reduce GHG emissions for several reasons. These include an existing Battelle Corporate initiative that seeks to monitor and reduce the corporate contribution to GHG emissions. As a research institution committed to making contributions in the areas of energy research and national security, INL has mission-based interests in the clean, sustainable production of energy. Its historical interest in nuclear reactor testing represents a longstanding commitment to low-carbon power generation.

INL is committed to sustainability. GHG inventory is an accepted method of identifying environmental impacts, and assessing major contributions to GHG emissions and the best methods to reduce them.

\subsubsection{Sustainable INL}

Sustainable INL is a newly launched program, part of a movement among federal agencies to evaluate current processes and establish goals for achieving sustainability. The Sustainable INL mission is to "ensure the nation's energy security with safe, competitive, and sustainable energy systems without compromising the ability of future generations to meet their own needs." Its intent is to continue 
innovation and research while simultaneously improving energy efficiency, becoming responsible environmental stewards, and conserving natural resources. Focus areas within the program include those covered in EO 13514: energy efficiency, renewable energy, toxics reductions, recycling, sustainable buildings, electronics stewardship, fleet efficiency, and water conservation. Sustainable INL is assisted by a Communities of Practice advisory group and relies on management and employee participation to achieve its goals. For questions specific to Sustainable INL, visit www.inl.gov/sustainable, or contact Chris Ischay (Program Manager, 208-526-4382, Christopher.ischay@inl.gov) or Ernest Fossum (Energy Manager, 208-526-2513, Ernest.fossum@,inl.gov). 


\section{APPROACH TO ESTABLISHING INL'S GHG BASELINE 3.1 Selected GHG Protocol}

As mentioned in Section 1, these calculations follow the Guidance and the TSD unless otherwise indicated.

\subsection{Defined Inventory Boundaries}

This GHG baseline considers all INL-owned operations, including buildings and employees. As mentioned in the Introduction, several other contractors operate on the INL Site including CH2M-WG Idaho, LLC (CWI), Bechtel BWXT Idaho, LLC (BBWI), and NRF. Facilities managed by these other contractors were not included in this baseline. Some non-INL employees (including DOE-ID) are located in several INL buildings that were included in these calculations, but since INL pays for the operations (e.g., boiler fuels, electricity, solid waste removal), and thus has operational control, these were counted in the INL baseline. Operations directly associated with the employees of other contractors (such as employee travel and employee commuting) were not included in INL's baseline GHG calculations.

The following metrics are offered in order to give a sense of scale for INL's contributions to the overall INL Site's GHG baseline:

- INL employees (including interns and temporary employees) amounted to almost 4,000 of the combined 8,000 (approximate) employees at the INL Site during FY08

- The total square footage of buildings owned by INL or occupied by INL personnel and used for INL operations represented $55 \%$ of the total 5.6 million square feet that made up the INL Site in FY08 $(58 \% \text { of } 563 \text { buildings })^{\text {a }}$

- The percentage of electrical power consumed by INL operations and personnel is $66.8 \%$ of the total 230,114 MWh.

\subsection{Defined Scope}

GHG inventories or footprints consider emissions from three emission scopes (Scope 1, 2, and 3) as indicated in Figure 2, and described below:

- $\quad$ Scope 1: Direct or INL-owned emissions that are produced onsite, such as stationary combustion (from fuel combustion), mobile combustion (from fleet vehicles) and fugitive emissions (from refrigerants, onsite landfills, and onsite wastewater treatment). These include emissions that may benefit another entity or contractor, but for which INL controls or owns the associated process.

- $\quad$ Scope 2: Indirect or shared emissions produced by INL's electricity, heat, and steam purchases. (Note that INL did not purchase heat or steam during FY08.)

- $\quad$ Scope 3: Indirect or shared emissions generated by outsourced activities that benefit INL (occur outside INL's organizational boundaries, but are a consequence of INL's activities). This can include a large number of activities, but for purposes of this inventory, INL focused on transmission and distribution losses, employee commuting, employee travel, contracted waste disposal and contracted wastewater treatment since these categories were identified as required in the TSD for FY08 baseline reporting. Other activities that could be included in Scope 3 include the embodied emissions of purchased materials.

a. These are based on the numbers at the end of the FY08 third quarter, which is considered representative for the entire year. INL's portion is based on the buildings that belong to the DOE Nuclear Energy program, while the remaining buildings at the INL Site belong to the Environmental Management program. 


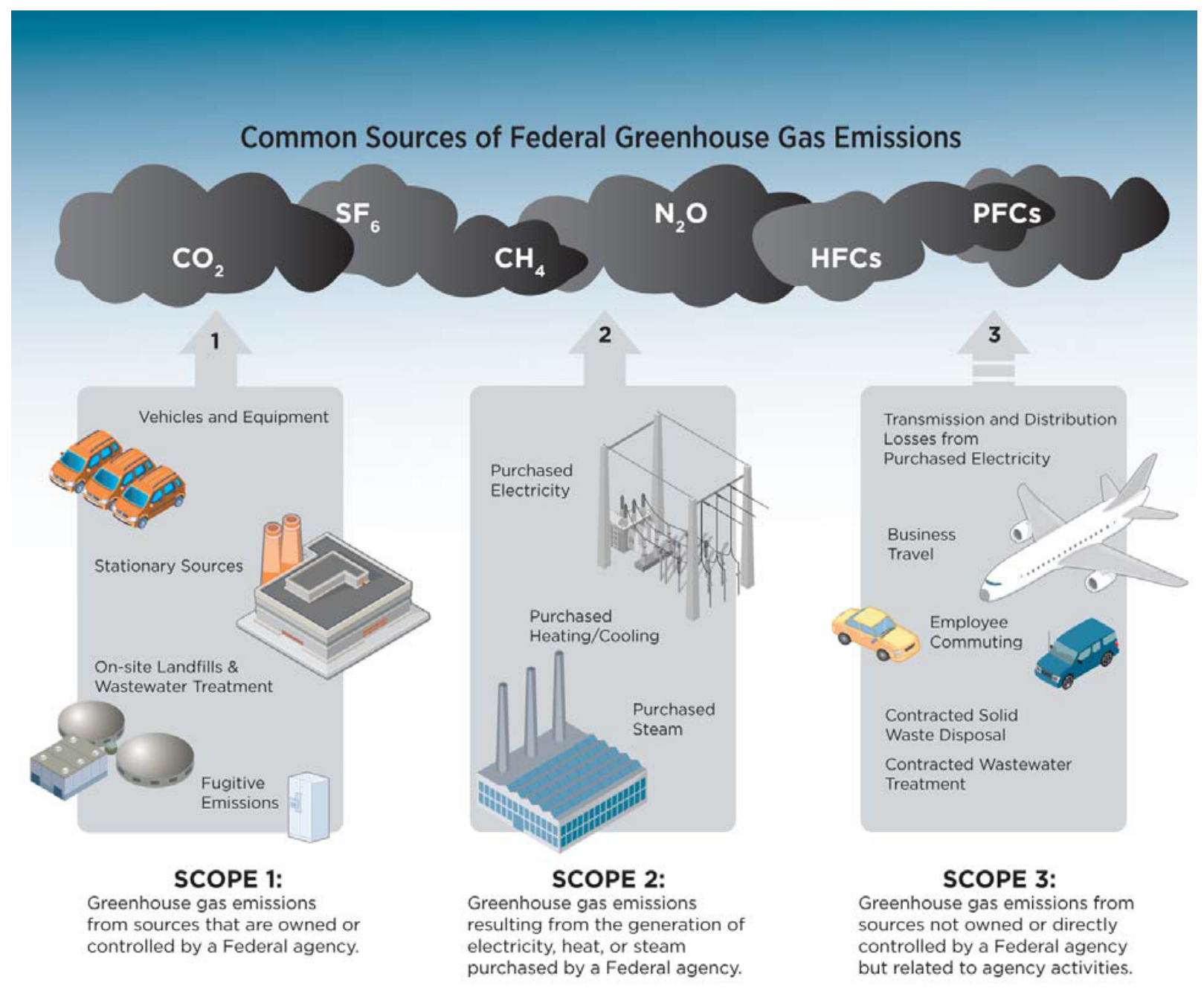

Figure 2. GHG emissions from Scope 1, 2, and 3.

This inventory considered the following six gases: $\mathrm{CO}_{2}, \mathrm{SF}_{6}, \mathrm{CH}_{4}, \mathrm{~N}_{2} \mathrm{O}, \mathrm{HFCs}$, and PFCs, as required by the Guidance. $\mathrm{NF}_{3}$ and other GHGs with high global warming potential (GWP) are identified for optional reporting.

The GWP of the gases considered was used to convert all GHG emissions to units of carbon dioxide equivalent $\left(\mathrm{CO}_{2} \mathrm{e}\right)$, a means of describing the cumulative effect of all greenhouse gases weighted by their 100 -year warming potential. The GWP indicates each gas's heat-trapping impact relative to $\mathrm{CO}_{2}$, which has a GWP of 1.0 and functions as a warming index. The GWP values used for the FY08 baseline are based on the EPA MRR and are shown in Appendix A.

The following table (Table 1) summarizes the GHG emissions categories that were identified in the Guidance and TSD, whether they were calculated for INL's FY08 baseline, and their reporting status in the Guidance and TSD (identified as required or recommended for an agency's FY08 baseline). Some Scope 3 GHG sources will not be required reporting until FY11 or later since the calculation method for determining their emissions is still being developed. 
Table 1. GHG emissions categories identified in Guidance and TSD.

\begin{tabular}{|c|c|c|c|}
\hline Scope & Emissions Category & $\begin{array}{l}\text { Calculated for } \\
\text { INL's FY08 } \\
\text { Baseline? }\end{array}$ & Reporting Status in Guidance and TSD \\
\hline \multirow{6}{*}{$\begin{array}{c}1 \\
\text { (Direct) }\end{array}$} & $\begin{array}{l}\text { Stationary Combustion } \\
\text { (Boilers, generators, etc.) }\end{array}$ & Yes & $\begin{array}{l}\text { Required reporting in FY08 Baseline } \\
\text { and FY10 Inventory. }\end{array}$ \\
\hline & $\begin{array}{l}\text { Mobile Combustion (Fleet } \\
\text { Vehicles) }^{\mathrm{b}}\end{array}$ & Yes & $\begin{array}{l}\text { Required reporting in FY08 Baseline } \\
\text { and FY10 Inventory. }\end{array}$ \\
\hline & $\begin{array}{l}\text { Fugitive Emissions: } \\
\text { Refrigerants }\end{array}$ & Yes & $\begin{array}{l}\text { Required reporting in FY08 Baseline } \\
\text { and FY10 Inventory. }\end{array}$ \\
\hline & $\begin{array}{l}\text { Fugitive Emissions: Onsite } \\
\text { Municipal Solid Waste } \\
\text { (MSW) Landfill }\end{array}$ & Yes & $\begin{array}{l}\text { Required reporting in FY08 Baseline } \\
\text { and FY10 Inventory. }\end{array}$ \\
\hline & $\begin{array}{l}\text { Fugitive Emissions: Onsite } \\
\text { Wastewater Treatment }\end{array}$ & Yes & $\begin{array}{l}\text { Required reporting in FY08 Baseline } \\
\text { and FY10 Inventory. }\end{array}$ \\
\hline & $\begin{array}{l}\text { Industrial Process Emissions } \\
\text { (Manufacturing or } \\
\text { Processing Chemicals or } \\
\text { Materials) }\end{array}$ & $\begin{array}{l}\text { No, INL does } \\
\text { not perform } \\
\text { any of the } \\
\text { activities } \\
\text { listed in the } \\
\text { TSD }\end{array}$ & $\begin{array}{l}\text { Required reporting in FY08 Baseline } \\
\text { and FY10 Inventory. }\end{array}$ \\
\hline \multirow{6}{*}{$\begin{array}{c}2 \\
\text { (Indirect) }\end{array}$} & Purchased Electricity & Yes & $\begin{array}{l}\text { Required reporting in FY08 Baseline } \\
\text { and FY10 Inventory. }\end{array}$ \\
\hline & $\begin{array}{l}\text { Purchased Steam, Hot Water } \\
\text { or Chilled Water }\end{array}$ & $\begin{array}{l}\text { No, INL does } \\
\text { not purchase }\end{array}$ & $\begin{array}{l}\text { Required reporting in FY08 Baseline } \\
\text { and FY10 Inventory. }\end{array}$ \\
\hline & $\begin{array}{l}\text { Combined Heating and } \\
\text { Power }\end{array}$ & $\begin{array}{l}\text { No, INL does } \\
\text { not utilize }\end{array}$ & $\begin{array}{l}\text { Required reporting in FY08 Baseline } \\
\text { and FY10 Inventory. }\end{array}$ \\
\hline & $\begin{array}{l}\text { Purchased Steam from } \\
\text { Waste to Energy }\end{array}$ & $\begin{array}{l}\text { No, INL does } \\
\text { not purchase }\end{array}$ & $\begin{array}{l}\text { Required reporting in FY08 Baseline } \\
\text { and FY10 Inventory. }\end{array}$ \\
\hline & $\begin{array}{l}\text { Transmission \& Distribution } \\
\text { (T\&D) Losses (within INL's } \\
\text { operational controls) }\end{array}$ & $\begin{array}{l}\text { Yes, included } \\
\text { in Purchased } \\
\text { Electricity } \\
\end{array}$ & $\begin{array}{l}\text { Required reporting in FY08 Baseline } \\
\text { and FY10 Inventory. }\end{array}$ \\
\hline & $\begin{array}{l}\text { Purchased Green Power } \\
\text { (Renewable Energy } \\
\text { Certificates [RECs]) }\end{array}$ & $\begin{array}{l}\text { Yes, INL } \\
\text { purchased } \\
\text { RECs }\end{array}$ & $\begin{array}{l}\text { Required reporting in FY08 Baseline } \\
\text { and FY10 Inventory. }\end{array}$ \\
\hline
\end{tabular}

b. This includes $\mathrm{CH}_{4}$ and $\mathrm{N}_{2} \mathrm{O}$ from biofuel blends. Per the TSD, biogenic $\mathrm{CO}_{2}$ emissions generated from combustion of biofuels are counted separately since this carbon would have been released through the plant's natural decomposition. 
Table 1. (continued).

\begin{tabular}{|c|c|c|c|}
\hline Scope & Emissions Category & $\begin{array}{l}\text { Calculated for } \\
\text { INL's FY08 } \\
\text { Baseline? }\end{array}$ & Reporting Status in Guidance and TSD \\
\hline \multirow{11}{*}{$\begin{array}{c}3 \\
\text { (Indirect) }\end{array}$} & $\begin{array}{l}\text { T\&D Losses (outside INL's } \\
\text { operational controls) }\end{array}$ & Yes & $\begin{array}{l}\text { Required reporting in FY08 Baseline } \\
\text { and FY10 Inventory. }\end{array}$ \\
\hline & Employee Commuting & Yes & $\begin{array}{l}\text { Required reporting in FY08 Baseline } \\
\text { and FY10 Inventory. }\end{array}$ \\
\hline & Business Air Travel & Yes & $\begin{array}{l}\text { Required reporting in FY08 Baseline } \\
\text { and FY10 Inventory. }\end{array}$ \\
\hline & $\begin{array}{l}\text { Business Ground Travel: } \\
\text { Rental Vehicle }\end{array}$ & Yes & $\begin{array}{l}\text { Required reporting in FY08 Baseline } \\
\text { and FY10 Inventory. }\end{array}$ \\
\hline & $\begin{array}{l}\text { Business Ground Travel: } \\
\text { Personal Vehicle }\end{array}$ & Yes & $\begin{array}{l}\text { Required reporting in FY08 Baseline } \\
\text { and FY10 Inventory. }\end{array}$ \\
\hline & Contracted MSW Disposal & Yes & $\begin{array}{l}\text { Required reporting in FY08 Baseline } \\
\text { and FY10 Inventory. }\end{array}$ \\
\hline & $\begin{array}{l}\text { Contracted Wastewater } \\
\text { Treatment }\end{array}$ & Yes & $\begin{array}{l}\text { Required reporting in FY08 Baseline } \\
\text { and FY10 Inventory. }\end{array}$ \\
\hline & $\begin{array}{l}\text { Vendor and Contractor } \\
\text { Emissions (Indirect } \\
\text { emissions in the supply } \\
\text { chain) }\end{array}$ & $\begin{array}{l}\text { No, will wait } \\
\text { for additional } \\
\text { guidance. }\end{array}$ & $\begin{array}{l}\text { Do not require reporting at this time, } \\
\text { but future inventories will include these } \\
\text { emissions. It's expected that this } \\
\text { category will be a large contributor to } \\
\text { INL's GHG inventory. }\end{array}$ \\
\hline & Fuel Production & No & $\begin{array}{l}\text { Do not require reporting at this time, } \\
\text { but future inventories are expected to } \\
\text { include these emissions. }\end{array}$ \\
\hline & $\begin{array}{l}\text { Land Management (changes } \\
\text { that sequester or release } \\
\text { GHGs) }\end{array}$ & No & Do not require reporting at this time. \\
\hline & $\begin{array}{l}\text { Biomass Combustion, } \\
\text { Enteric Fermentation, } \\
\text { Composting and Manure } \\
\text { Management }\end{array}$ & $\begin{array}{l}\text { No, INL does } \\
\text { not perform. }\end{array}$ & Do not require reporting at this time. \\
\hline \multirow{3}{*}{ Biogenic $^{c}$} & Mobile Combustion. & Yes & $\begin{array}{l}\text { Required reporting in FY08 Baseline } \\
\text { and FY10 Inventory. }\end{array}$ \\
\hline & Stationary Combustion & $\begin{array}{l}\text { No, INL did } \\
\text { not utilize } \\
\text { biofuels for } \\
\text { this category. }\end{array}$ & $\begin{array}{l}\text { Required reporting in FY08 Baseline } \\
\text { and FY10 Inventory. }\end{array}$ \\
\hline & $\begin{array}{l}\text { Fugitive Emissions: Onsite } \\
\text { MSW Landfill }\end{array}$ & Yes & $\begin{array}{l}\text { Required reporting in FY08 Baseline } \\
\text { and FY10 Inventory. }\end{array}$ \\
\hline
\end{tabular}

c. Note that biogenic emissions will not count against GHG reduction targets. 
As shown in Table 1, the TSD differentiates between anthropogenic and biogenic emissions for reporting purposes. Anthropogenic emissions are those that are human caused, while biogenic emissions are considered to be those that would have been released due to naturally occurring processes (without human involvement). For example, when considering the combustion of biofuels versus fossil fuels: the carbon from biofuels is absorbed from the atmosphere during plant growth and then would be recycled during the natural decomposition process and is therefore considered biogenic, while the carbon from fossil fuels has been locked in the earth for millennia and will yield a net increase in atmospheric carbon relative to what would have occurred naturally. Although the TSD requires reporting of biogenic emissions, they will not count against an agency's GHG reduction targets; therefore, INL will focus on their anthropogenic emissions.

\subsection{Identified Greenhouse Gas Emissions Categories}

After identifying which GHG emission categories in Table 1 would need to be calculated for INL, the next step is to identify where to find the INL-specific organizational data for performing the calculations. Table 2 summarizes the INL-specific data sources for each emissions category.

Table 2. INL's GHG emissions categories for Scopes 1, 2, and 3.

\begin{tabular}{|c|c|c|}
\hline Scope & Emissions Category & INL Data Source \\
\hline \multirow{5}{*}{$\begin{array}{c}1 \\
\text { (Direct) }\end{array}$} & $\begin{array}{l}\text { Stationary Combustion (Boilers, } \\
\text { generators, etc.) }\end{array}$ & $\begin{array}{l}\text { Fuel consumption reports (INL's } \\
\text { Quarterly Energy Reports) }\end{array}$ \\
\hline & Mobile Consumption (Fleet Vehicles) & $\begin{array}{l}\text { Fuel consumption databases (FAST and } \\
\text { TIMS) }\end{array}$ \\
\hline & Fugitive Emissions: Refrigerants & $\begin{array}{l}\text { Refrigerant purchases, use and disposal } \\
\text { (Comply Plus Database) }\end{array}$ \\
\hline & Fugitive Emissions: Onsite MSW Landfill & INL Landfill records (INWMIS) \\
\hline & $\begin{array}{l}\text { Fugitive Emissions: Onsite Wastewater } \\
\text { Treatment }\end{array}$ & $\begin{array}{l}\text { INL's Environmental Support \& Services } \\
\text { staff }\end{array}$ \\
\hline \multirow{2}{*}{$\begin{array}{c}2 \\
\text { (Indirect) }\end{array}$} & Purchased Electricity & INL's Quarterly Energy Reports \\
\hline & Purchased RECs & RECs Purchase Documentation \\
\hline \multirow{7}{*}{$\begin{array}{c}3 \\
\text { (Indirect) }\end{array}$} & $\mathrm{T} \& \mathrm{D}$ Losses & INL's Quarterly Energy Reports \\
\hline & Employee Commuting & $\begin{array}{l}\text { Employees' home ZIP Code and work } \\
\text { location (Human Resources) }\end{array}$ \\
\hline & Business Air Travel & INL Travel Office \\
\hline & Business Ground Travel: Rental Vehicle & INL Travel Office \\
\hline & $\begin{array}{l}\text { Business Ground Travel: Personal } \\
\text { Vehicle }\end{array}$ & INL Travel Office \\
\hline & Contracted MSW Disposal & $\begin{array}{l}\text { City of Idaho Falls Sanitation invoice } \\
\text { records }\end{array}$ \\
\hline & Contracted Wastewater Treatment & City of Idaho Falls \\
\hline
\end{tabular}

The identification of sources of information for the different emissions allows for the:

- Collection of necessary data from sources identified in Table 2.

- Gathering of necessary emissions factors (the TSD was consulted as a primary document, and then the EPA's Climate Leaders guidance was referenced if the applicable emissions factors were not available in the TSD). 
- Calculating inventory of INL's GHG emissions categories. For each emissions category, the GHG emissions were calculated in metric tons of $\mathrm{CO}_{2} \mathrm{e}$ based on INL-specific data, emission factor, and applicable GWP. (A sample calculation is shown in Appendix C.) The majority of these calculations were performed following the TSD, with Excel spreadsheets prepared specifically for establishing INL's GHG baseline. Exceptions to this process are noted in the sections below and include the emissions from the onsite municipal solid waste (MSW) landfill, which were calculated using an EPA model (per the TSD). All Excel spreadsheets used for calculations were validated internally by Michael Reed, Senior Process Analyst with INL’s Advanced Process and Decision Systems Department. 


\section{DISCUSSION AND RESULTS OF INL'S GHG BASELINE 4.1 Summary}

Table 3 and Figure 3 through Figure 5 summarize the results of INL's GHG baseline for FY08. Details on the emission factors and calculation methods used, as well as a discussion of the individual results, follow in the sections below.

Table 3. Results of INL's GHG baseline for FY08.

\begin{tabular}{|c|c|c|}
\hline Scope & Emissions Category & $\begin{array}{c}\text { GHC Emissions } \\
\left(\mathrm{MT} \mathrm{CO}_{2} \mathrm{e}\right)\end{array}$ \\
\hline \multirow{6}{*}{$\begin{array}{c}1 \\
\text { (Direct) }\end{array}$} & Stationary Combustion & 15,343 \\
\hline & Mobile Combustion & 10,038 \\
\hline & Fugitive Emissions: Refrigerants & 245 \\
\hline & Fugitive Emissions: Onsite MSW Landfill & 10,219 \\
\hline & Fugitive Emissions: Onsite Wastewater Treatment & 132 \\
\hline & SCOPE 1 TOTAL & 35,977 \\
\hline \multirow{3}{*}{$\begin{array}{c}2 \\
\text { (Indirect) }\end{array}$} & Purchased Electricity $^{\mathrm{d}}$ & 63,278 \\
\hline & Purchased RECs & $-3,474$ \\
\hline & SCOPE 2 TOTAL & 59,804 \\
\hline \multirow{8}{*}{$\begin{array}{c}3 \\
\text { (Indirect) }\end{array}$} & Transmission \& Distribution Losses & 1,141 \\
\hline & Employee Commuting & 9,711 \\
\hline & Business Air Travel & 6,687 \\
\hline & Business Ground Travel: Rental Vehicle & 351 \\
\hline & Business Ground Travel: Personal Vehicle & 516 \\
\hline & Contracted MSW Disposal & 12 \\
\hline & Contracted Wastewater Treatment & 56 \\
\hline & SCOPE 3 TOTAL & 18,474 \\
\hline \multicolumn{2}{|r|}{ TOTAL ANTHROPOGENIC EMISSIONS } & 114,256 \\
\hline \multirow[t]{3}{*}{ Biogenic } & Mobile Combustion & 162 \\
\hline & Fugitive Emissions: Onsite MSW Landfill & 1,335 \\
\hline & Contracted MSW Disposal & 2 \\
\hline \multicolumn{2}{|r|}{ TOTAL BIOGENIC EMISSIONS } & 1,499 \\
\hline \multicolumn{2}{|r|}{ TOTAL EMISSIONS (ANTHROPOGENIC + BIOGENIC) } & 115,755 \\
\hline
\end{tabular}

d. As discussed in Section 4.3, this value includes Transmission \& Distribution losses within INL's operational controls (INL owns the T\&D lines at the Site). 


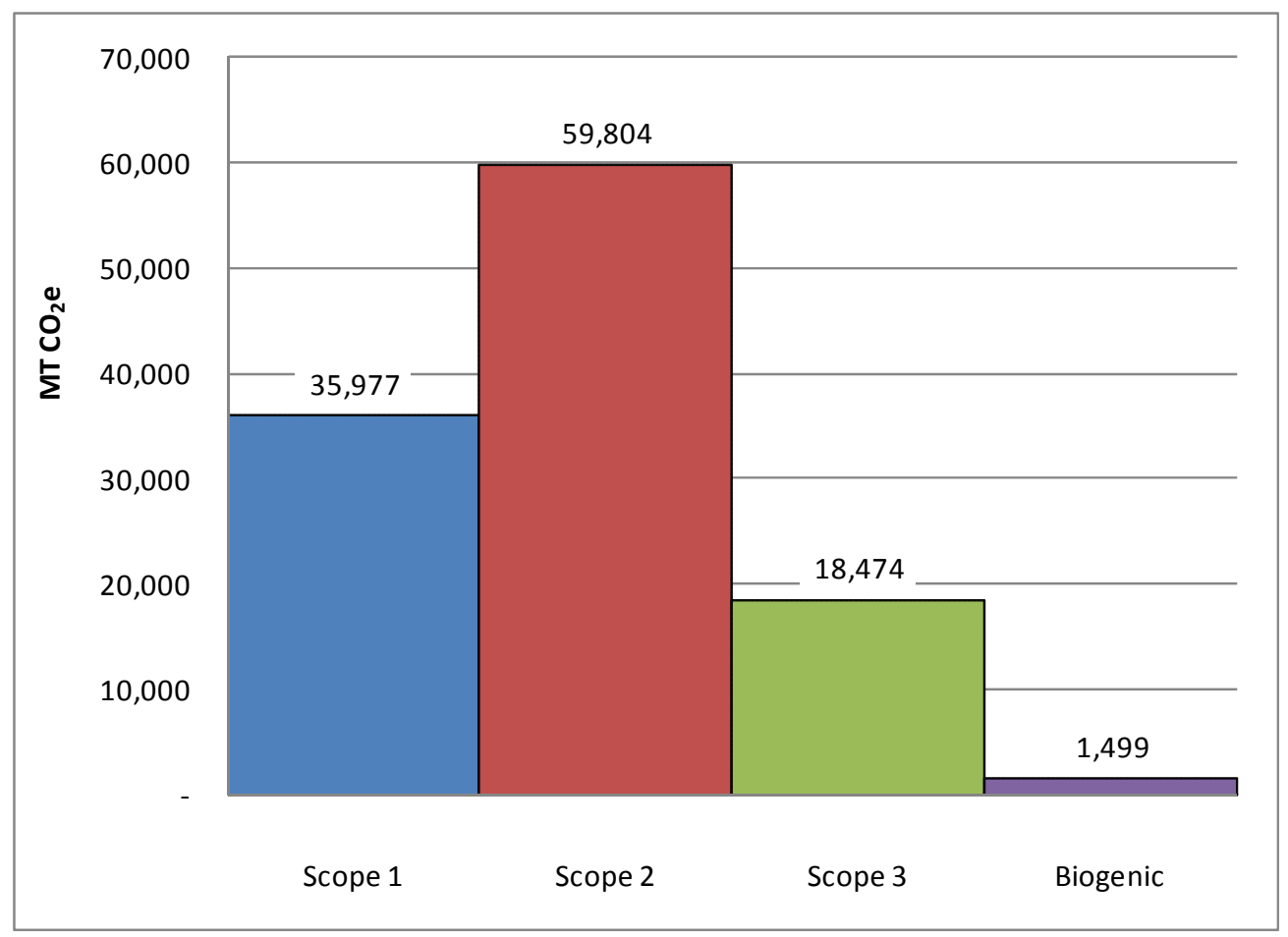

Figure 3. INL's FY08 GHG baseline results, by scope.

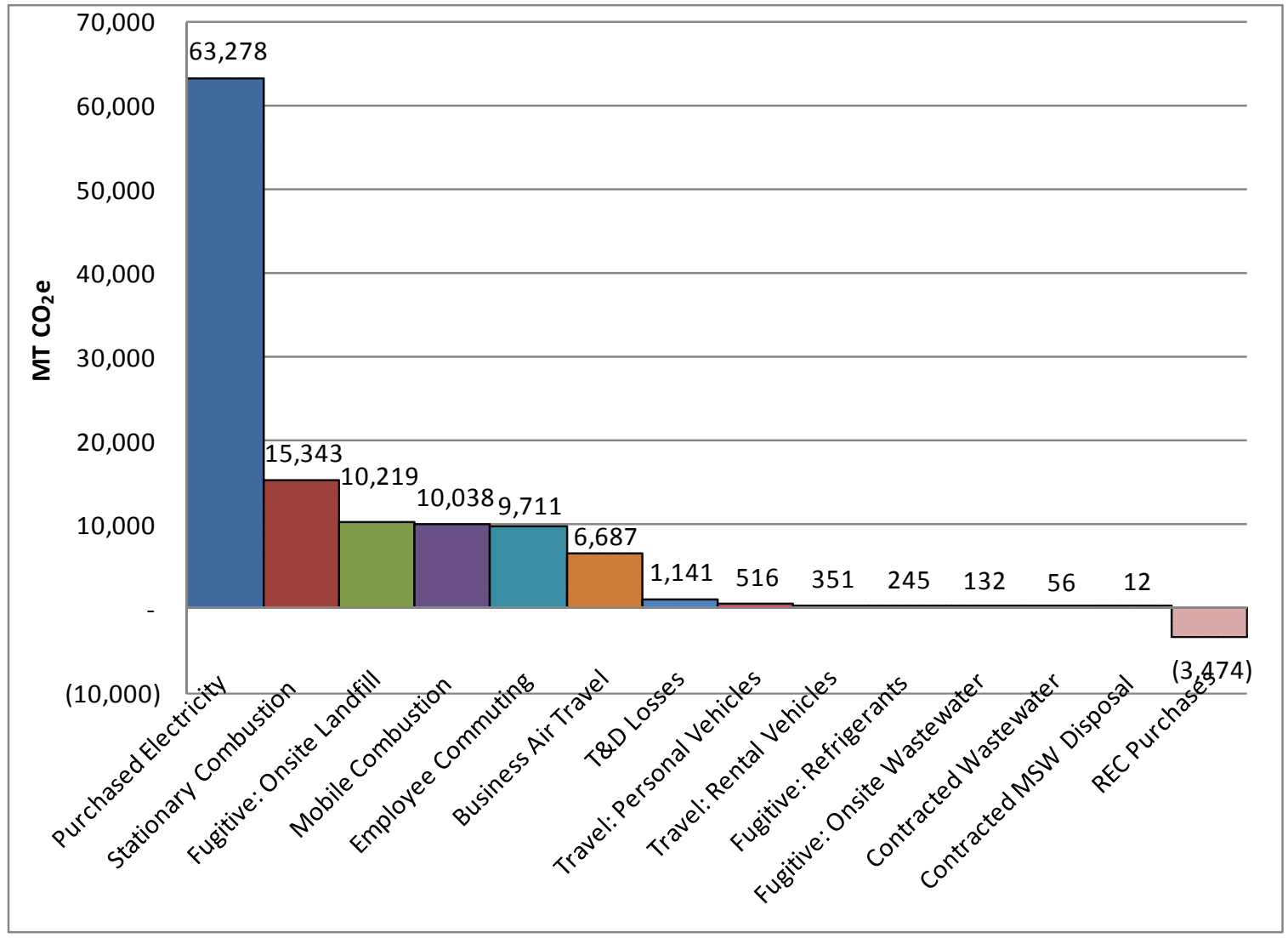

Figure 4. INL's FY08 GHG baseline results, from largest to smallest emissions category, excluding biogenic emissions. 


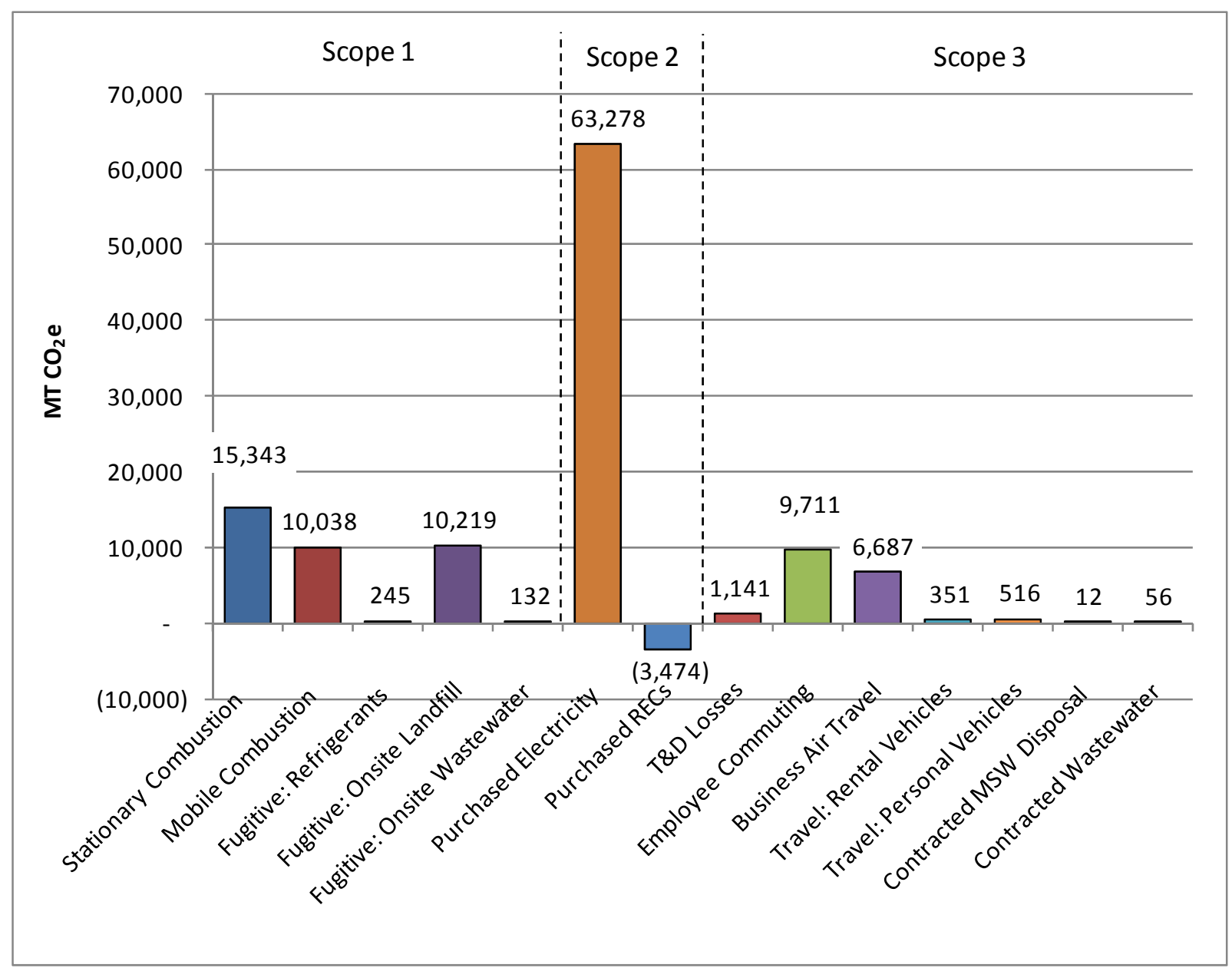

Figure 5. INL's FY08 GHG baseline results, by scope and emissions category, excluding biogenic emissions.

\subsection{Scope One - Direct Emissions}

INL's FY08 Scope 1 emissions are summarized in Figure 6. A discussion of each of the Scope 1 emissions categories follows and includes the calculation methods, the significance of the results, and lessons learned from the data collection and calculation process. 


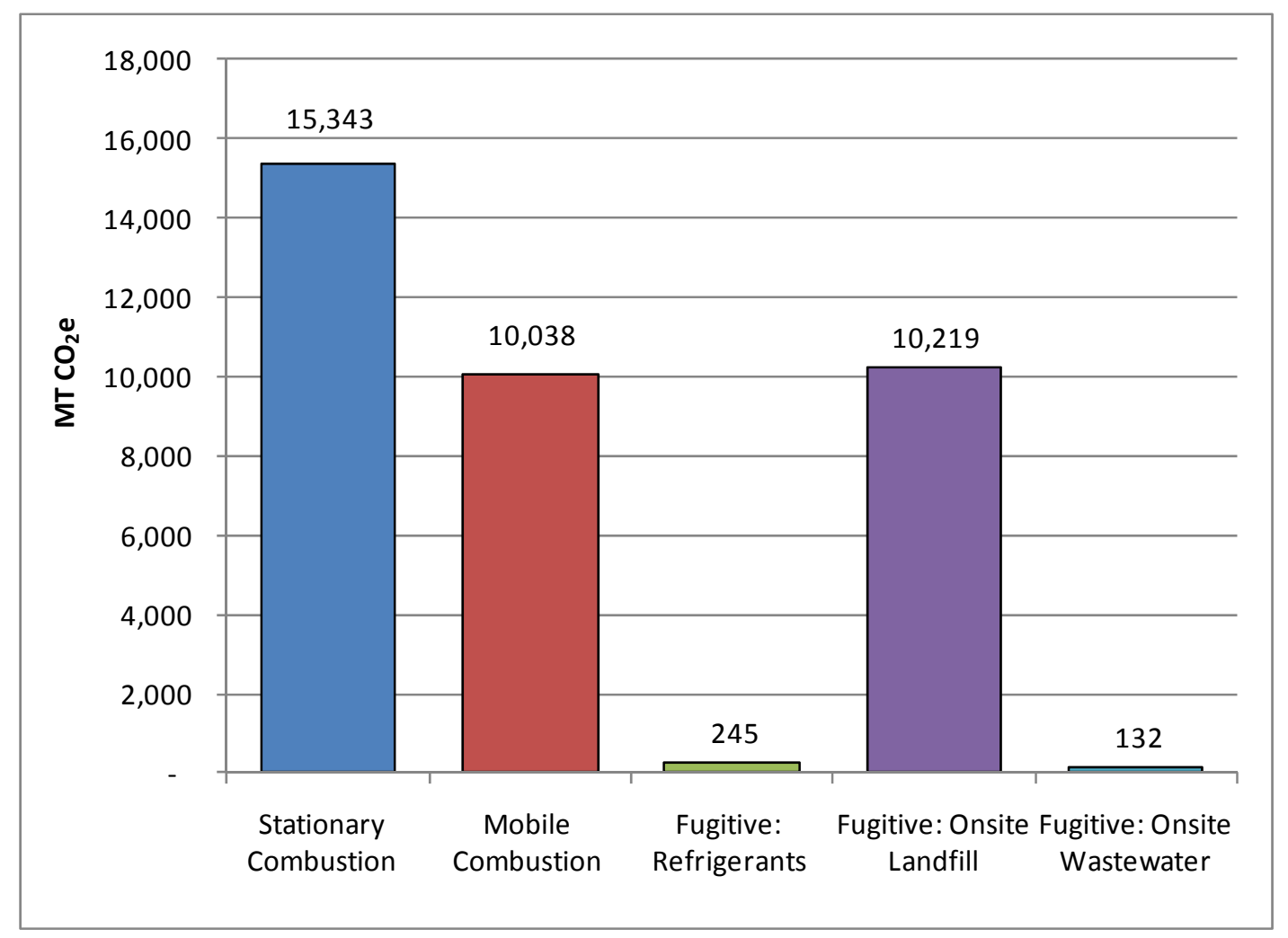

Figure 6. INL's FY08 GHG baseline results for Scope 1.

\subsubsection{Stationary Combustion Emissions}

\subsubsection{Calculation Method}

To estimate the GHG emissions of INL's stationary combustion from boilers and generators, the default methodology identified in the TSD was adopted. This consisted of looking at the total amount of fuels used (purchased) onsite by INL. Since these data are also submitted for the Federal Energy Management Program (FEMP) Energy Report, and are already tracked for the INL Site, the only calculations needed were to isolate the emissions that INL owns from those owned by other INL Site contractors by separating the fuels purchased for INL operated facilities.

\subsubsection{Results Discussion}

During FY08 INL used the types and amounts of fuel shown in Table 4 for stationary combustion.

Table 4. Amounts of fuel used for stationary combustion at INL during FY08.

\begin{tabular}{|l|c|l|c|}
\hline \multirow{2}{*}{\multicolumn{1}{|c|}{ Energy Type }} & \multicolumn{2}{c|}{ Fuel Used } & \multirow{2}{*}{$\begin{array}{c}\text { GHG Emissions } \\
\left(\mathrm{MT} \mathrm{CO}_{2} \mathrm{e}\right)\end{array}$} \\
\cline { 2 - 3 } & Amount & \multicolumn{1}{c|}{ Units } & $12,771.23$ \\
\hline Fuel Oil No. 2 & $1,247,088$ & Gallons & 320.69 \\
\hline Liquefied Natural Gas (LNG) & 43,590 & Gallons & 994.94 \\
\hline Liquefied Propane Gas (LPG) & 171,038 & Gallons & $1,256.46$ \\
\hline Natural Gas (Pipeline) & 236,746 & Therms & $15,343.32$ \\
\hline \multicolumn{2}{|r}{ TOTAL } \\
\hline
\end{tabular}


As shown in Table 4, INL's stationary combustion emissions were calculated to produce 15,343.32 $\mathrm{MT} \mathrm{CO}_{2} \mathrm{e}$. This equates to $42.6 \%$ of INL's Scope 1 emissions, and $13.4 \%$ of the total FY08 anthropogenic emissions considered.

Since these data are already collected and reported annually for the FEMP Energy Report, they are considered to be of high quality.

\subsubsection{Lessons Learned}

Since the data are already gathered at INL for the FEMP Energy Report, no changes are needed for reporting in future years. In addition, the data are considered accurate, with all of INL-owned sources of stationary combustion included.

\subsubsection{Mobile Combustion Emissions}

INL operates a large vehicle fleet that includes everything from light-duty passenger vehicles to commercial buses to off-road equipment. This fleet is being modernized by a variety of methods, including transition to GSA vehicles. INL's commercial buses are used for transporting other INL Site contractor employees, as well as BEA employees, on their commute to and from the Site facilities. Since INL owns the bus operations for all Site contractors, these emissions are considered Scope 1 for INL.

\subsubsection{Calculation Method}

To calculate the GHG emissions from INL's mobile combustion sources, a combination of the default and advanced methodology from the TSD were used. INL tracks fuel usage by vehicle type for its annual submittal to the Federal Automated Statistical Tool (FAST), which tracks fuels used for road vehicles (when fuel taxes are paid), and also with fuel sheets for off-road equipment (for which no fuel taxes are paid).

Since the amount of each type of fuel consumed by general vehicle type (buses, light-duty trucks, light-duty cars, equipment, and trucks) was known (see Table 5), more specific $\mathrm{CH}_{4}$ and $\mathrm{N}_{2} \mathrm{O}$ emission factors were used then what is assumed for the default calculation. However, two additional variables were not known: the number of miles driven and the vehicle model year. For this reason, conservative assumptions were made on the emission control technology as indicated in Appendix B.

\subsubsection{Results Discussion}

During FY08, INL used a combination of fossil fuels and biofuels to power its diverse vehicle fleet. Since the $\mathrm{CO}_{2}$ emissions for biofuels are to be considered separately (as biogenic emissions) per the $\mathrm{TSD},{ }^{\mathrm{e}}$ their GHG emissions were calculated separately. The types and amounts of fossil fuels and biofuels are shown in Table 5 and Table 6, respectively.

e. Although a controversial position, the pending TSD states that biogenic emissions in the form of $\mathrm{CO}_{2}$ emissions generated from biofuel combustion are to be counted separately since this carbon would have been released through the plant's natural decomposition. The $\mathrm{CH}_{4}$ and $\mathrm{N}_{2} \mathrm{O}$ emissions from the combustion of biofuel blends are not considered biogenic emissions. 
Table 5. Amounts of fossil fuels used for mobile combustion at INL during FY08.

\begin{tabular}{|l|l|r|r|}
\hline \multicolumn{1}{|c|}{ Fuel Type } & \multicolumn{1}{|c|}{ Vehicle Type } & \multicolumn{1}{c|}{$\begin{array}{c}\text { Fuel Used } \\
(\mathrm{gal})\end{array}$} & $\begin{array}{c}\text { GHG Emissions } \\
\left(\mathrm{MT} \mathrm{CO}_{2} \mathrm{e}\right)\end{array}$ \\
\hline Compressed Natural Gas (CNG) & Buses & 90.00 & 0.68 \\
\hline & Light Duty Car & 54.30 & 0.43 \\
\hline & Light Duty Truck & 437.40 & 3.43 \\
\hline & Buses & $544,548.50$ & $5,561.14$ \\
\hline & Equipment & $50,229.00$ & 517.32 \\
\hline & Light Duty Truck & $14,566.31$ & 148.78 \\
\hline Gasoline & Truck & $45,827.20$ & 468.38 \\
\hline & Buses & $2,391.50$ & 21.06 \\
\hline & Equipment & $5,803.10$ & 51.39 \\
\hline & Light Duty Car & $15,529.40$ & 141.15 \\
\hline & Light Duty Truck & $241,424.42$ & $2,228.42$ \\
\hline LNG & Truck & $6,811.90$ & 63.13 \\
\hline & Buses & $45,964.30$ & 348.44 \\
\hline Propane & Light Duty Truck & 30.00 & 0.24 \\
\hline & Equipment & 851.90 & 5.04 \\
\hline & & TOTAL & $10,032.25$ \\
\hline
\end{tabular}

Table 6. Amounts of biofuels used for mobile combustion at INL during FY08.

\begin{tabular}{|c|c|c|c|c|}
\hline Fuel Type & Vehicle Type & $\begin{array}{l}\text { Fuel Used } \\
\text { (gal) }\end{array}$ & $\begin{array}{c}\text { GHG } \\
\text { Emissions } \\
\left(\mathrm{MT} \mathrm{CO}_{2} \mathrm{e}\right)\end{array}$ & $\begin{array}{l}\text { Biogenic } \\
\text { Emissions } \\
\left(\mathrm{MT} \mathrm{CO}_{2} \mathrm{e}\right)\end{array}$ \\
\hline \multirow[t]{4}{*}{ B15 Biodiesel Blend ${ }^{\mathrm{f}}$} & Buses & $50,677.20$ & 439.94 & 71.85 \\
\hline & Equipment & 77.10 & 0.67 & 0.11 \\
\hline & Light Duty Truck & 36.70 & 0.32 & 0.05 \\
\hline & Truck & 819.40 & 7.12 & 1.16 \\
\hline \multirow[t]{2}{*}{ E85 Ethanol Fuel Blend } & Light Duty Car & $2,063.20$ & 3.41 & 10.08 \\
\hline & Light Duty Truck & $16,195.00$ & 27.31 & 79.14 \\
\hline \multicolumn{3}{|c|}{ 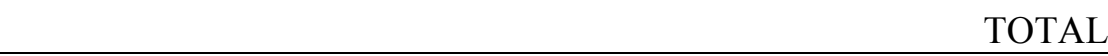 } & 5.56 & 162.39 \\
\hline
\end{tabular}

As shown in Table 5 and Table 6, INL's mobile combustion emissions were calculated to produce 10,037.81 MT CO $2 \mathrm{e}\left(10,032.25 \mathrm{MT} \mathrm{CO}_{2} \mathrm{e}\right.$ from fossil fuels and 5.56 $\mathrm{MT} \mathrm{CO}_{2} \mathrm{e}$ from biofuels). This equates to $27.9 \%$ of INL's Scope 1 emissions, and $8.8 \%$ of the total FY08 anthropogenic emissions considered.

Since these data are already collected and reported annually in the FAST system, they are considered to be of high quality, although the exact biodiesel blend (B10 or B20) could be better tracked.

f. Carol Comstock clarified in a December 10, 2009 phone call that BEA utilizes a combination of B10 (used in winter) and B20 (used in summer), and the exact amounts of each blend are not currently tracked (at least not in such a way that can easily be reported). Assume a 50/50 split of B10 and B20, and therefore refer to the biodiesel blend as B15. 


\subsubsection{Lessons Learned}

Since the data for calculating GHG emissions from mobile combustion are already gathered at INL for the FAST system, no changes are needed for reporting in future years in order to continue to use the default calculation method. However, as discussed above, the accuracy could be improved if the exact blends of biofuel were tracked, as well as total miles driven (along with gallons of fuel) and more specific vehicle information, including model and year.

Overall, the data utilized for the default calculation are considered accurate, with all of INL-owned sources of mobile combustion included.

\subsubsection{Fugitive Emissions: Refrigerants}

Fugitive emissions from refrigerants and fluorinated gases are those GHG emissions from equipment and vehicles that are not captured or destroyed by an emissions control system (those that do not pass through a stack, chimney, etc.).

\subsubsection{Calculation Method}

DOE Headquarters (DOE-HQ) publicized a data call in late 2009 for each facility's fugitive emissions from refrigerants and fluorinated gases that focused on the gases listed in Table 7, identified by their Chemical Abstract Service (CAS) number. In order to evaluate INL's fugitive emissions during FY08, data from the following sources was reviewed:

- Purchase, usage, and disposal data contained in Comply Plus, INL's chemical inventory database

- Use and disposal information contained on Refrigeration Service Records

- Transaction detail reports pulled from Comply Plus database for each CAS Number

- Integrated Waste Tracking System (IWTS) database queries to identify any additional disposal of refrigerants.

Queries were run in Comply Plus for the different outcomes during FY08 using the CAS numbers. Additionally, INL obtained hard copies of the refrigerant service records. These records were reviewed to determine if there was a difference between the amount of refrigerant recovered from a system and its total full capacity. If less refrigerant was recovered than the system's full charge amount, the difference was determined to have been released (used). If there was no difference, then there was no release. Additionally, if the refrigerant service record indicated the equipment would be disposed, any difference from the amount recovered and the full charge was considered a released (used) amount. If refrigerants were disposed, the quantity indicated on the refrigerant service record was included as disposed on the spreadsheet. Transaction detail reports were run in Comply Plus for each CAS number for the specific date range to ensure no duplicate entries from the refrigerant service record and the information maintained in Comply Plus. Any duplicate data was removed from the total amount reported. IWTS was also queried for CAS numbers to ensure any waste disposed was captured in the total amount reported.

This methodology aligns with the default methodology presented in the TSD. INL relied on information contained in the Comply Plus inventory database and on hard copy maintenance records for HVAC systems and vehicles. The amounts of fluorinated gases emitted were calculated as detailed in examples in the TSD (depending on the original units of the gas included in the database or on the maintenance record).

\subsubsection{Results Discussion}

Using the method described above, the fugitive refrigerant emissions in Table 7 were considered for their contribution to INL's GHG emissions during FY08. The refrigerants are organized in the table according to their GHG emissions; a majority of the gases evaluated were not considered to have any 
releases during FY08, but they are listed in the table to show that they have been evaluated. Also shown in the table is the GWP of each gas, which indicates each gas heat-trapping impact relative to $\mathrm{CO}_{2}$.

Table 7. Fugitive refrigerants evaluated for GHG emissions during FY08 at INL

\begin{tabular}{|c|c|c|c|}
\hline Common Name & GWP & $\begin{array}{l}\text { Mass Emitted } \\
\text { (lbs) }\end{array}$ & $\begin{array}{c}\text { GHG Emissions } \\
\left(\mathrm{MT} \mathrm{CO}_{2} \mathrm{e}\right)\end{array}$ \\
\hline HFC-125 & 2,800 & 88.9750 & 113.00 \\
\hline HFC-134a & 1,300 & 173.1543 & 102.10 \\
\hline HFC-32 & 650 & 71.9900 & 21.23 \\
\hline HFC-23 & 11,700 & 0.4313 & 2.29 \\
\hline PFC-116 & 9,200 & 0.5063 & 2.11 \\
\hline HFC-152a & 140 & 23.8795 & 1.52 \\
\hline HFC-365mfc & 794 & 3.8616 & 1.39 \\
\hline HFC-43-10mee & 1,300 & 1.6875 & 1.00 \\
\hline HFC-143a & 3,800 & 0.1950 & 0.34 \\
\hline $\mathrm{SF}_{6}$ - Sulfur Hexafluoride & 23,900 & 0.0000 & 0.00 \\
\hline HFC-41 & 150 & 0.0000 & 0.00 \\
\hline HFC-134 & 1,000 & 0.0000 & 0.00 \\
\hline HFC-143 & 300 & 0.0000 & 0.00 \\
\hline HFC-152 & 53 & 0.0000 & 0.00 \\
\hline HFC-161 & 12 & 0.0000 & 0.00 \\
\hline $\mathrm{HFC}-227 \mathrm{ca}$ & NA & 0.0000 & 0.00 \\
\hline HFC-227ea & 2,900 & 0.0000 & 0.00 \\
\hline HFC-236cb & 1,340 & 0.0000 & 0.00 \\
\hline HFC-236fa & 6,300 & 0.0000 & 0.00 \\
\hline HFC-236ea & 1,370 & 0.0000 & 0.00 \\
\hline $\mathrm{HFC}-245 \mathrm{ca}$ & 560 & 0.0000 & 0.00 \\
\hline HFC-245fa & 1,030 & 0.0000 & 0.00 \\
\hline HFC-c-447-ef & NA & 0.0000 & 0.00 \\
\hline PFC-14 & 6,500 & 0.0000 & 0.00 \\
\hline PFC-218 & 7,000 & 0.0000 & 0.00 \\
\hline PFC-318 or PFCc318 & 8,700 & 0.0000 & 0.00 \\
\hline PFC-3-1-10 & 7,000 & 0.0000 & 0.00 \\
\hline PFC-4-1-12 & 7,500 & 0.0000 & 0.00 \\
\hline PFC-5-1-14 & 7,400 & 0.0000 & 0.00 \\
\hline PFC-9-1-18 & 7,500 & 0.0000 & 0.00 \\
\hline $\mathrm{C}-\mathrm{C}_{3} \mathrm{~F}_{6}$ & 17,340 & 0.0000 & 0.00 \\
\hline $\mathrm{SF}_{5} \mathrm{CF}_{3}$ & 17,700 & 0.0000 & 0.00 \\
\hline $\mathrm{NF}_{3}$ & 17,200 & 0.0000 & 0.00 \\
\hline \multicolumn{3}{|r|}{ TOTAL } & 244.97 \\
\hline
\end{tabular}


This equates to $0.7 \%$ of INL's Scope 1 emissions, and $0.2 \%$ of the total FY08 anthropogenic emissions considered.

\subsubsection{Lessons Learned}

The accuracy of the data used to calculate GHG emissions from fluorinated gases are hard to verify as the maintenance records are completed by hand and stored in hard copy. It is difficult to be assured that all of the maintenance records have been reviewed, including fluorinated gas charges. There is some overlap in data contained on the maintenance records and that contained in Comply Plus. Comply Plus was used to verify the amounts of refrigerants emitted and the volumes reported on the maintenance records. During the data compilation, some duplicate and some missing information was identified. Discrepancies were resolved by contacting maintenance personnel to verify system charges.

It may be helpful to have electronic data gathering at point of entry (i.e., maintenance personnel enter the data directly into an electronic system that updates to Comply Plus automatically, removing one potential source of error in data entry). Also, this would eliminate the requirement to obtain hard copies of the maintenance records and remove one source of information to review during the calculations.

\subsubsection{Fugitive Emissions: Onsite MSW Landfill}

INL utilized a combination of both an onsite and offsite (contracted) landfill for MSW disposal during FY08. These Scope 1 calculations look at the emissions associated with MSW disposal in the onsite landfill at the Central Facilities Area (CFA), while the Scope 3 calculations look at the emissions associated with contracted MSW disposal from town facilities that go to an offsite landfill.

INL operates the landfill at CFA, which accepts waste from all INL Site contractors. The CFA landfill currently includes one open designated area for MSW that has been receiving waste since 1984. Three other designated MSW areas have been opened and closed since 1947 and are no longer receiving waste. The CFA landfill has no landfill gas collection or destruction, is not subject to Title V reporting, and has no formalized operating permit. A daily soil cover is applied to produce an estimated overall soil to trash ratio of one to one. Of the 198 acres currently designated as landfill space at CFA, 70 acres have been designated for MSW, although only a portion of this area is currently being utilized ${ }^{\mathrm{g}}$.

\subsubsection{Calculation Method}

In order to determine the Scope 1 emissions associated with INL's onsite landfill, the historical quantities of MSW were pulled from the Idaho National Engineering and Environmental Laboratory (INEEL) Nonradiological Waste Management Information System (INWMIS) database. INWMIS tracks the amounts (by both weight and volume) and types of waste collected from each Site facility for delivery to the CFA landfill. INWMIS tracks multiple types of waste, including a number of types of construction and demolition waste. For this calculation, only two categories of waste in INWMIS were considered, Category 1 and 2 for "regular trash" and "cafeteria waste," respectively.

EPA's Landfill Gas Emissions Model (LandGEM) was used to calculate the GHG emissions associated with the CFA landfill, as identified in the TSD methodology. LandGEM utilizes the mass of MSW disposed from the year the landfill was opened until the year it was closed. The historical data shown in Table 8 were input to LandGEM to get the estimated annual amounts of $\mathrm{CO}_{2}$ (biogenic) and $\mathrm{CH}_{4}$ (anthropogenic) produced. These calculations only considered the open MSW portion of the CFA landfill (open since 1984) and ignored the three MSW areas that have been closed. Since INWMIS only includes data starting in 1992, the MSW amounts for 1984 through 1991 were estimated based on an average trend from the available data (average of the previous 5 years). The MSW disposed of in the CFA landsite is documented in Table 8.

\footnotetext{
${ }^{g}$ CFA landfill information is based on correspondence with Norm Stanley during August 2010.
} 
Table 8. Amount of MSW produced by INL during FY08 for disposal in onsite CFA landfill.

\begin{tabular}{|c|c|}
\hline Fiscal Year & $\begin{array}{c}\text { Amount of MSW } \\
\text { (tons) }\end{array}$ \\
\hline 1984 & $15,196.35$ \\
\hline 1985 & $15,196.35$ \\
\hline 1986 & $15,196.35$ \\
\hline 1987 & $15,196.35$ \\
\hline 1988 & $15,196.35$ \\
\hline 1989 & $15,196.35$ \\
\hline 1990 & $15,196.35$ \\
\hline 1991 & $15,196.35$ \\
\hline 1992 & $40,540.28$ \\
\hline 1993 & $8,308.58$ \\
\hline 1994 & $13,707.36$ \\
\hline 1995 & $9,178.26$ \\
\hline 1996 & $4,247.27$ \\
\hline 1997 & $1,436.32$ \\
\hline 1998 & $3,479.26$ \\
\hline 1999 & $1,135.21$ \\
\hline 2000 & $1,091.80$ \\
\hline 2001 & 972.30 \\
\hline 2002 & $1,099.19$ \\
\hline 2003 & $1,299.64$ \\
\hline 2004 & $1,639.89$ \\
\hline 2005 & $1,070.45$ \\
\hline 2006 & $1,754.07$ \\
\hline 2007 & $1,145.95$ \\
\hline 2008 & 826.64 \\
\hline 2009 & 620.55 \\
\hline TOTAL & $215,123.75$ \\
\hline
\end{tabular}

\subsubsection{Results Discussion}

INL's disposal of MSW in the onsite landfill at CFA during FY08 is estimated to contribute 10,219.01 $\mathrm{MT} \mathrm{CO}_{2} \mathrm{e}$ anthropogenic emissions and 1,335.17 $\mathrm{MT} \mathrm{CO}_{2} \mathrm{e}$ biogenic emissions to the GHG inventory. The anthropogenic emissions equate to $28.4 \%$ of INL's Scope 1 emissions, and $8.9 \%$ of the total FY08 anthropogenic emissions considered.

\subsubsection{Lessons Learned}

Since INL currently tracks the quantities and types of materials sent to the onsite landfill at CFA, the data used are considered accurate, and no changes are needed for streamlining the calculation in future years. However, additional searching may identify the amounts landfilled prior to 1992, which had to be estimated for this calculation. These historical amounts will be especially important if the final TSD calls 
for reporting emissions from closed landfills (the CFA landfill contains three areas that collected MSW prior to 1984 that have since been closed and these were not included in the GHG calculations).

\subsubsection{Fugitive Emissions: Onsite Wastewater Treatment}

At its Site facilities, INL operates its own wastewater treatment, which consists of a combination of lagoons and septic systems. Evaporative lagoons are located at the major facilities, while septic tanks are located at the smaller or remote locations, including Experimental Breeder Reactor I, Specific Manufacturing Capability (SMC) fire station, the Gun Range, the main INL guard gate, and the Critical Infrastructure Test Range Complex (CITRC) (formerly known as the Special Power Excursion Test Reactor [SPERT] Tests II, III, and IV). Since the septic tanks are used by only a small percentage of INL's population, their associated GHG emissions were not considered for these calculations.

INL also operates a number of lagoons (including evaporative ponds) for industrial waste. Since this industrial waste does not contain significant amounts of organics, they were not considered in these calculations.

\subsubsection{Calculation Method}

INL's data on onsite lagoons used for wastewater treatment are identified by facility in Table 9. INL's Human Resources department provided the employee counts at each facility for the employee commuting calculations (Scope 3, Section 4.4.2). The number of visitors to each facility was estimated based on 5\% of the number of employees.

Table 9. FY08 population data by facility for onsite wastewater treatment calculations.

\begin{tabular}{|l|c|c|c|}
\hline \multicolumn{1}{|c|}{ Facility Name } & Number of Employees & Number of Visitors & $\begin{array}{c}\text { Total Population } \\
\text { Considered }\end{array}$ \\
\hline ATR & 459.25 & 22.96 & 482.21 \\
\hline CFA & 552.25 & 27.61 & 579.86 \\
\hline MFC & 716.75 & 35.84 & 752.59 \\
\hline SMC & 253.25 & 12.66 & 265.91 \\
\hline & 1981.50 & 99.08 & $2,080.58$ \\
\hline
\end{tabular}

The population data from Table 9 were used with the calculation method in the TSD, and the default national averages (from the TSD) for the specific treatment process.

\subsubsection{Results Discussion}

INL's onsite wastewater treatment during FY08 is estimated to contribute $132.12 \mathrm{MT} \mathrm{CO}_{2} \mathrm{e}$ emissions to the GHG inventory. This equates to $0.4 \%$ of INL's Scope 1 emissions, and $0.1 \%$ of the total FY08 anthropogenic emissions considered.

\subsubsection{Lessons Learned}

For future inventories it is believed that site-specific data and the factors unique to INL would produce more accurate results than calculations based on national averages. In addition, future calculations for individual septic systems and industrial waste treatment should be included, even though these are likely minimal GHG contributors relative to the lagoons.

\subsection{Scope Two - Indirect Emissions}

A discussion of INL's FY08 Scope 2 emissions categories follows, including the calculation methods, the significance of the results, and lessons learned from the data collection and calculation process. 


\subsubsection{Purchased Electricity and Renewable Energy Certificates Emissions}

\subsubsection{Calculation Method}

These calculations follow the default methodology of electricity purchases reported for the FEMP Energy Report. Amounts are determined based on a combination of monthly electrical bills and INL's onsite electricity meters. Since these data are also submitted in the FEMP Energy report, they are already tracked for the INL Site, and the only calculations needed were to isolate the emissions that INL owns (consumed in INL operated facilities) from the other INL Site contractors.

INL purchases electricity from four different electrical utilities to support the operations of its different facilities. Idaho Falls Power supplies electricity to the town facilities. Idaho Power supplies electricity to the Site facilities as well as some small locations outside of Idaho Falls city limits, and Rocky Mountain Power and Lost River Electrical Company provide electricity to some of the smaller buildings and equipment outside of Idaho Falls city limits, including lighting at some bus lots. The breakdown in electrical purchases by electrical provider is shown in Table 10.

INL purchased a total of 153,764.20 MWh during FY08, with 30,365.20 MWh provided to non-Site locations, and 123,399.00 MWh going to INL facilities at the INL Site. Per the TSD, the emission factors for purchased electricity are determined according to the EPA's Emissions \& Generation Resource Integrated Database (eGRID) and the eGRID subregion in which the facility is located. eGRID's subregional emission factors are based on plant-specific data in that region, as reported to the EPA, the Energy Information Administration (EIA), and the Federal Energy Regulatory Commission (FERC). (For more information on eGRID, refer to www.epa.gov/cleanenergy/energy-resources/egrid.) All INL facilities are located in the "WECC Northwest" eGRID subregion, the Northwest Power Pool (NWPP).

Table 10. INL's FY08 electrical purchases by location and provider.

\begin{tabular}{|c|c|c|c|}
\hline Location & $\begin{array}{c}\text { Owner of } \\
\text { T\&D System }\end{array}$ & Electrical Provider & $\begin{array}{c}\text { Electricity Purchased } \\
(\mathrm{MWh})\end{array}$ \\
\hline INL Site & INL & $\begin{array}{l}\text { Idaho Power (includes } \\
\text { T\&D losses) }\end{array}$ & $123,399.00$ \\
\hline \multicolumn{3}{|r|}{ SUB-TOTAL (Site) } & $123,399.00$ \\
\hline $\begin{array}{l}\text { Assorted locations (excludes } \\
\text { INL Site) }\end{array}$ & $\begin{array}{l}\text { Electrical } \\
\text { Provider }\end{array}$ & Idaho Power & 54.94 \\
\hline Town Facilities & $\begin{array}{l}\text { Electrical } \\
\text { Provider }\end{array}$ & Idaho Falls Power & $30,150.21$ \\
\hline $\begin{array}{l}\text { Assorted locations outside } \\
\text { INL Site and Idaho Falls city } \\
\text { limits }\end{array}$ & $\begin{array}{l}\text { Electrical } \\
\text { Provider }\end{array}$ & $\begin{array}{l}\text { Lost River Electric } \\
\text { Company }\end{array}$ & 2.81 \\
\hline $\begin{array}{l}\text { Assorted locations outside } \\
\text { INL Site and Idaho Falls city } \\
\text { limits }\end{array}$ & $\begin{array}{l}\text { Electrical } \\
\text { Provider }\end{array}$ & Rocky Mountain Power & 157.25 \\
\hline \multicolumn{3}{|r|}{ SUB-TOTAL (Non-Site) } & $30,365.20$ \\
\hline \multicolumn{3}{|r|}{ GROSS TOTAL } & $153,764.20$ \\
\hline Sterling, Texas & $\begin{array}{l}\text { Not } \\
\text { Applicable }\end{array}$ & RECs & $-6,600.00$ \\
\hline \multicolumn{3}{|r|}{ NET TOTAL } & $147,164.20$ \\
\hline
\end{tabular}


The TSD calls for differentiating between transmission and distribution (T\&D) losses within INL's operational controls and those outside INL's operational controls as Scope 2 and 3, respectively, based on whether the organization owns the associated transmission lines. In order to facilitate this differentiation, electricity purchases in Table 10 are identified by the facility location at which they were utilized. Since INL owns the electrical grid at the Site, and the T\&D losses are considered within INL's operational controls, the electricity purchase for the Site from Idaho Power shown in Table 10 includes the associated T\&D losses. (The Scope 3 T\&D losses [outside INL's operational controls] are based on electrical purchases for non-Site locations where INL does not own the T\&D system.)

In addition to the electricity purchased directly for its facilities, INL purchased 6,600 MWh of Renewable Energy Certificates (RECs) in FY08 from a wind power facility in Texas to offset a portion of its carbon emissions. INL did not actually purchase renewable energy, but rather purchased the RECs or certified environmental benefits of the renewable energy generated in another region to support the growth and expansion of the renewable energy industry as a whole. INL is credited for the GHG emissions that this renewable energy did not emit. See Attachment 1 for the receipt, which includes details on INL's RECs purchase. The emission factors for the RECs purchased in FY08 are based on the wind power facility located in Sterling, Texas, and "ERCOT All" eGRID subregion (the subregion was determined using the ZIP Code for Sterling City and EPA's Power Profiler Web site [www.epa.gov/cleanenergy/energy-resources/egrid]).

\subsubsection{Results Discussion}

Table 11 shows that the purchased electricity, less RECs, amounts to 59,804.43 $\mathrm{MT} \mathrm{CO}_{2} \mathrm{e}$, which is all of INL's Scope 2 emissions and 52.3\% of the net total FY08 anthropogenic emissions considered. Figure 7 shows the FY08 results for purchased electricity and RECs.

Table 11. INL's GHG emissions from electricity purchased in FY08.

\begin{tabular}{|c|c|}
\hline \multicolumn{1}{|c|}{ Emissions Category } & $\begin{array}{c}\text { GHG Emissions } \\
\left(\mathrm{MT} \mathrm{CO}_{2} \mathrm{e}\right)\end{array}$ \\
\hline $\begin{array}{l}\text { Purchased Electricity (includes T\&D losses within INL's } \\
\text { operational controls) }\end{array}$ & $63,278.05$ \\
\hline Purchased RECs (displaced GHG emissions) & $-3,473.62$ \\
\hline NET TOTAL & $59,804.43$ \\
\hline
\end{tabular}




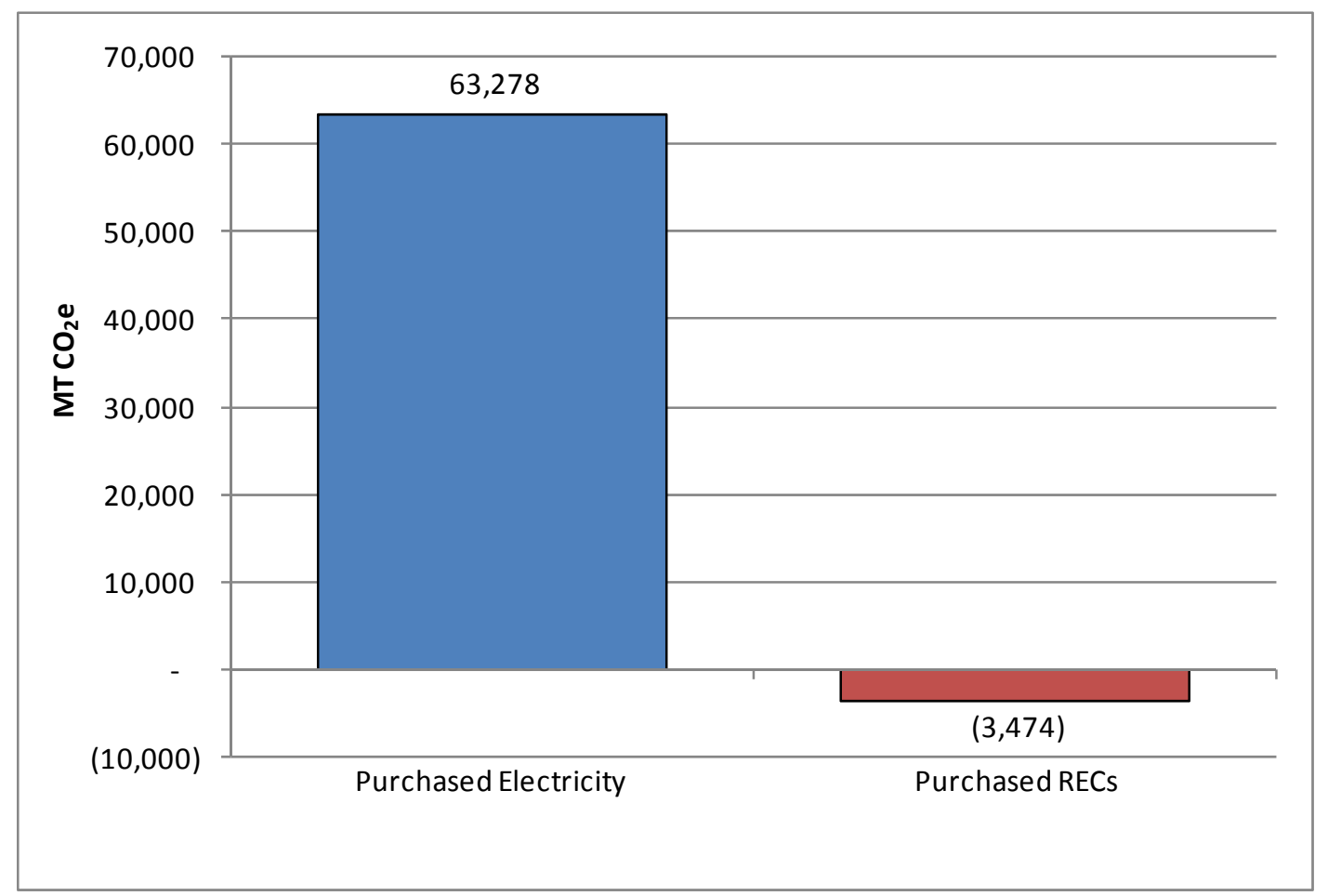

Figure 7. INL's FY08 GHG baseline results for Scope 2.

\subsubsection{Lessons Learned}

Since these data are already collected and reported annually for the FEMP energy reports, they are considered to be of high quality.

\subsection{Scope Three - Indirect Emissions}

INL's FY08 Scope 3 emissions are summarized in Figure 8. A discussion of each of the Scope 3 emissions categories follows and includes the calculation methods, the significance of the results, and lessons learned from the data collection and calculation process. 


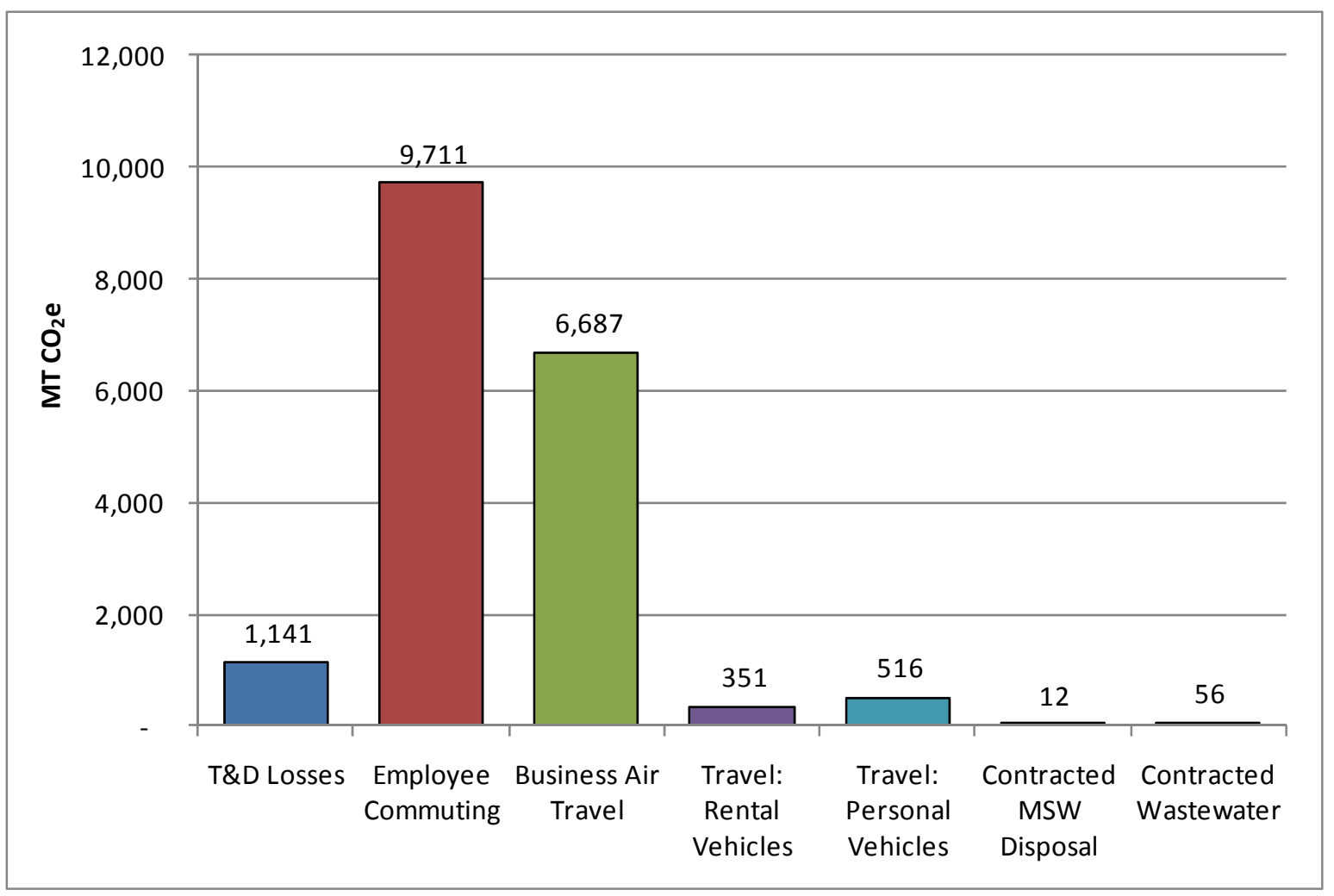

Figure 8. INL's FY08 GHG baseline results for Scope 3.

\subsubsection{Transmission and Distribution Loss Emissions}

\subsubsection{Calculation Method}

The TSD provides only a default calculation methodology for determining the GHG emissions from T\&D losses outside INL's operational control. This method assumes the national average T\&D loss factor of $6.18 \%$ for purchased electricity, and utilizes the same eGRID subregion emission factors used for Scope 2 purchased electricity (www.epa.gov/cleanenergy/energy-resources/egrid). As stated in Section 4.3.1.1, since INL owns the electrical grid at the Site, the TSD indicates that the associated T\&D losses be included in the GHG emissions reported for Scope 2, Purchased Electricity. Since the TSD differentiates between T\&D losses inside and outside of INL's operational controls, these Scope 3 T\&D losses are based on INL's electrical purchases outside the INL Site, for locations where INL does not own the T\&D lines. Therefore, these T\&D losses are based on the non-Site subtotal in Table 10. As a result, they account for only a small portion of the electricity consumed by INL (30,365.20 MWh of a total $153,764.20 \mathrm{MWh}$ purchased, or $20 \%$ of the total gross electricity purchase).

\subsubsection{Results Discussion}

A T\&D loss of $6.18 \%$ equates to 2,001.07 MWh for INL's FY08 electricity purchase outside INL's operational controls (not provided to the Site), and 1,141.45 $\mathrm{MT} \mathrm{CO}_{2} \mathrm{e}$ of emissions. This equates to $6.2 \%$ of INL's Scope 3 emissions, and 1.0\% of the total FY08 anthropogenic emissions considered.

\subsubsection{Lessons Learned}

Since this calculation is simply based on a percentage of the GHG emissions presented for INL's Scope 2 electricity purchases, the data used are considered accurate, and no changes are needed for streamlining the calculation in future years. 


\subsubsection{Employee Commuting Emissions}

\subsubsection{Calculation Method}

The TSD has identified emissions from employee commuting as recommended, but not required for FY08. The methodology identified is to use an employee survey. Since it would be difficult to expect responses in FY10 for a survey looking at employee commuting behaviors during FY08, available data was gathered and combined with appropriate assumptions as described below.

Initial information for this calculation was obtained from INL's Human Resources department, which provided the number of employees at a particular home ZIP Code and work location (by major facility) for the end of each quarter in FY08. These numbers for each quarter were then averaged for the year. A number of assumptions were made in order to determine the total number of miles that INL employees commuted to work during FY08 using their personal vehicles. These assumptions are described below. In general, assumptions were made to err on the conservative side. It should be noted that, with the exception of the INL bus system for employees who work at the Site, the Idaho Falls area does not have a significant public transportation system, and therefore all commuting outside of the INL buses was assumed to have been completed in employees' personal vehicles.

The distance of a daily commute were estimated based on the following parameters:

- Commute distance was based on the distance between an employee's home ZIP Code and their work location using Google Maps.

- For workers with an unknown home ZIP Code, or a commute greater than 2 hours (based on home ZIP Code and work location in Google Maps), it was assumed that they have an alternative living situation in Idaho Falls (e.g., a second home).

- If an employee's work location was off-Site or unknown, an average annual commute was used for United States workers of 16 miles one-way (http://abcnews.go.com/Technology/Traffic/story?id=485098\&page=1).

In estimating the number of employees who commute to work, the following assumptions were made:

- Assume that $20 \%$ of town employees living in Pocatello carpool to their work location with two employees per vehicle.

- Assume that $1 \%$ of town employees living in Idaho Falls take an emission-free transportation source to work (this is an attempt to average the number of walkers and bikers across the year to account for greater participation during the warmer months and minimal participation during the winter).

- Assume 55\% bus ridership for INL's employees at Site facilities (MFC, CFA, ATR, and SMC) based on average bus ticket purchases (as provided by Marc Carroll, Former Fleet Manager). These employees were removed from the commuting calculations with the exception of their drive to the bus.

- Assume each bus rider drives 1-mile each way to their bus stop for a total of 2 miles per work day. (This is a conservative estimate based on bus routes during FY08 driving through neighborhoods.) In FY10, the INL buses began implementing a park-and-ride schema where the buses followed more streamlined routes and employees used large parking lots along the routes; thus, they likely drive farther to get to their individual bus stops.)

- Assume that $20 \%$ of INL's employees at Site facilities (MFC, CFA, ATR, and SMC) carpool to their work location with two employees per vehicle. 
The type of personal vehicle (mileage, fuel type, etc.) influences the calculation in the following ways:

- Assume that employee commute miles are divided with 50\% completed in passenger cars and $50 \%$ in light-duty trucks/vans/SUVs

- Assume no alternative fuels, only gasoline-powered vehicles, were used (conservative assumption).

The number of work days per year was calculated based on schedules which are specific to site locations:

- Determine work schedule based on work location:

- $\quad$ Town and MFC employees work a 9-80s schedule or 9 work days every 2 weeks

- $\quad$ All other Site employees (CFA, ATR, and SMC) work a 4-10s schedule of 4 work days every week.

- Assume that each employee takes 5 work-weeks off each year with 2 weeks of holidays (standard INL allotment for all employees) and 3 weeks of personal leave (this is the minimum INL allotment for combined sick and vacation leave and increases based on years of service).

- Did not account for part-time workers since these consist of a small component of the work force, for which the work schedules are difficult to determine (so far as they influence number of times driving to work per week [this is conservative]).

A survey would be preferable for computing the GHG emissions of the employee commute in future years, but the calculations will still need to include some assumptions to account for average commuting behaviors across the year (i.e., employees may switch work locations or commute vehicle during the year). The survey results will also need to be extrapolated, an acceptable calculation method per the TSD since a $100 \%$ response rate is very unlikely.

\subsubsection{Results Discussion}

INL's employee commuting GHG emissions in FY08 were estimated to be 9,710.60 MT $\mathrm{CO}_{2} \mathrm{e}$. This equates to $52.6 \%$ of INL's Scope 3 emissions, and $8.5 \%$ of the total FY08 anthropogenic emissions considered.

As a comparison to validate the employee commute calculation and the various assumptions described above, a simplified calculation was performed assuming that all employees traveled an average American commute of 16 miles one-way in a light-duty passenger car. This comparison calculation yielded an emissions value of 9,553.04 $\mathrm{MT} \mathrm{CO}_{2} \mathrm{e}$.

\subsubsection{Lessons Learned}

As discussed above, a survey would be a preferred means of better capturing INL employee's actual commuting behaviors. This is being considered for the FY10 GHG emissions inventory.

\subsubsection{Business Air Travel Emissions}

INL employees took 10,499 trips during FY08, as indicated by submitted and approved travel request forms. Such forms are submitted by employees to the INL travel office to make necessary reservations for both domestic and international travel on behalf of the Laboratory. Travel request forms are also submitted to secure insurance coverage for employees on travel and, thus, there are times when a form is submitted and no travel arrangements are necessary (this could lead to no Scope 3 GHG emissions calculated, for example, in the case where an employee uses an INL fleet vehicle or is carpooling in another employee's personal vehicle to an offsite location).

Each trip can include commercial airline and/or ground travel (in both personal and rental cars). Ground travel by taxi, bus, or rail is less common and is currently only tracked as a dollar value when an 
employee requests reimbursement. For the FY08 baseline GHG calculations, only employees travelling by commercial airline, personal vehicle and rental vehicle were included. Travel by taxi, bus, rail, and other commercial means is not currently tracked; furthermore, they are considered de minimis when compared to these other transportation means, especially airline travel. It is also considered likely that INL travelers with large ground transportation needs will rent a car, rather than take public transportation; thus, these emissions are included in INL's FY08 inventory.

INL travel requests are submitted by full-time INL employees as well as by subcontractors and student interns. If an employee is performing work for others, their trip may be paid for and arranged by the external entity, and thus these data would not be tracked by the INL travel office nor included in the airline miles reported. This would also apply to tracking the associated personal and rental car miles.

\subsubsection{Calculation Method}

The pending TSD only provides one calculation method (the default methodology) for calculating the GHGs of airline travel, which is to submit the Passenger Name Record (PNR), a travel record created for each air travel trip. Utilizing the PNRs allows the GHG emissions associated with each airline trip to be calculated automatically behind the scenes by GSA's Travel Management Information Service, based on specific and actual flight data (including the class of travel, length of each flight segment, and the passenger load). Since INL's travel office did not have the PNRs readily available, the actual flight miles traveled were used since this data was readily provided by the travel vendor. This data was supplied as passenger miles per trip from the starting airport to the destination airport, but did not include data on the individual flight legs (where the traveler changed flight legs), or the class of travel that would have allowed for more specific emission factors (based on short, medium, or long-haul flight miles, and/or class of service). Therefore, INL's total passenger miles for FY08 were simply multiplied by average emission factors per mile of commercial flight.

\subsubsection{Results Discussion}

Table 12 shows that the 24,419,454 passenger miles flown by INL employees during FY08 resulted in an estimated 6,687.35 $\mathrm{MT} \mathrm{CO}_{2} \mathrm{e}$, or $0.274 \mathrm{MT} \mathrm{CO}_{2} \mathrm{e}$ per 1,000 passenger miles. This equates to $36.2 \%$ of INL's Scope 3 emissions, and 5.9\% of the total FY08 anthropogenic emissions considered.

Table 12. Number of miles flown by INL employees during FY08.

\begin{tabular}{|l|c|c|}
\hline \multicolumn{1}{|c|}{ Type of Miles } & $\begin{array}{c}\text { Number of } \\
\text { Passenger Miles }\end{array}$ & $\begin{array}{c}\text { GHG Emissions } \\
\left(\mathrm{MT} \mathrm{CO}_{2} \mathrm{e}\right)\end{array}$ \\
\hline Domestic & $18,861,146$ & $5,165.19$ \\
\hline International & $5,558,308$ & $1,522.16$ \\
\hline TOTAL & $24,419,454$ & $6,687.35$ \\
\hline
\end{tabular}

\subsubsection{Lessons Learned}

A greater confidence could be assigned to this calculation of GHG emissions if additional data-such as a breakdown of miles in short, medium, and long-haul flights, as well as the passenger class - could be provided, but it is not likely the additional effort would provide results that are significantly different.

\subsubsection{Business Ground Travel: Rental Vehicle Emissions}

\subsubsection{Calculation Method}

For calculating the GHG emissions from rental vehicles, the INL travel office was able to provide the total number of miles that INL employees traveled during FY08 by each vehicle class. This data was provided by the rental car vendor. 
Vehicle classes were divided into two categories: passenger cars and light-duty trucks/vans/SUVs. The emission factors from the TSD were applied accordingly based on these two categories.

This calculation process followed the TSD's advanced methodology since the number of miles traveled in each rental car class was known (the default methodology called for making assumptions on the numbers of vehicle miles per rental car use).

\subsubsection{Results Discussion}

As shown in Table 13, INL's rental car use resulted in $350.82 \mathrm{MT} \mathrm{CO}_{2} \mathrm{e}$. This equates to $1.9 \%$ of INL's Scope 3 emissions, and $0.3 \%$ of the total FY08 anthropogenic emissions considered.

Table 13. Number of miles flown by INL employees during FY08.

\begin{tabular}{|r|c|c|}
\hline \multicolumn{1}{|c|}{ Vehicle Class } & $\begin{array}{c}\text { Number of Vehicle } \\
\text { Miles }\end{array}$ & $\begin{array}{c}\text { GHG Emissions } \\
\left(\mathrm{MT} \mathrm{CO}_{2} \mathrm{e}\right)\end{array}$ \\
\hline Passenger Cars & 499,500 & 187.10 \\
\hline Light-duty truck/van/SUV & 306,413 & 163.72 \\
\hline TOTAL & 805,913 & 350.82 \\
\hline
\end{tabular}

\subsubsection{Lessons Learned}

Since the number of miles traveled in rental vehicles is already tracked by the rental car vendors, these data are considered to be of high quality, and no changes are needed for tracking the data in future years.

\subsubsection{Business Ground Travel: Personal Vehicle Emissions}

\subsubsection{Calculation Method}

In FY08 travel-expense reports were completed through paper hard copies, and the only method to determine the number of vehicle-miles completed in personal cars for business travel was to review these expense reports by hand. Therefore, it was decided to use a representative sample to determine the total number of personal vehicle-miles traveled. Of the 10,499 trips submitted for approval during FY08, 500 of their corresponding expense reports were sampled. These results are summarized in Figure 9 and Figure 10. An average mileage per trip of 592.6 miles was calculated. 


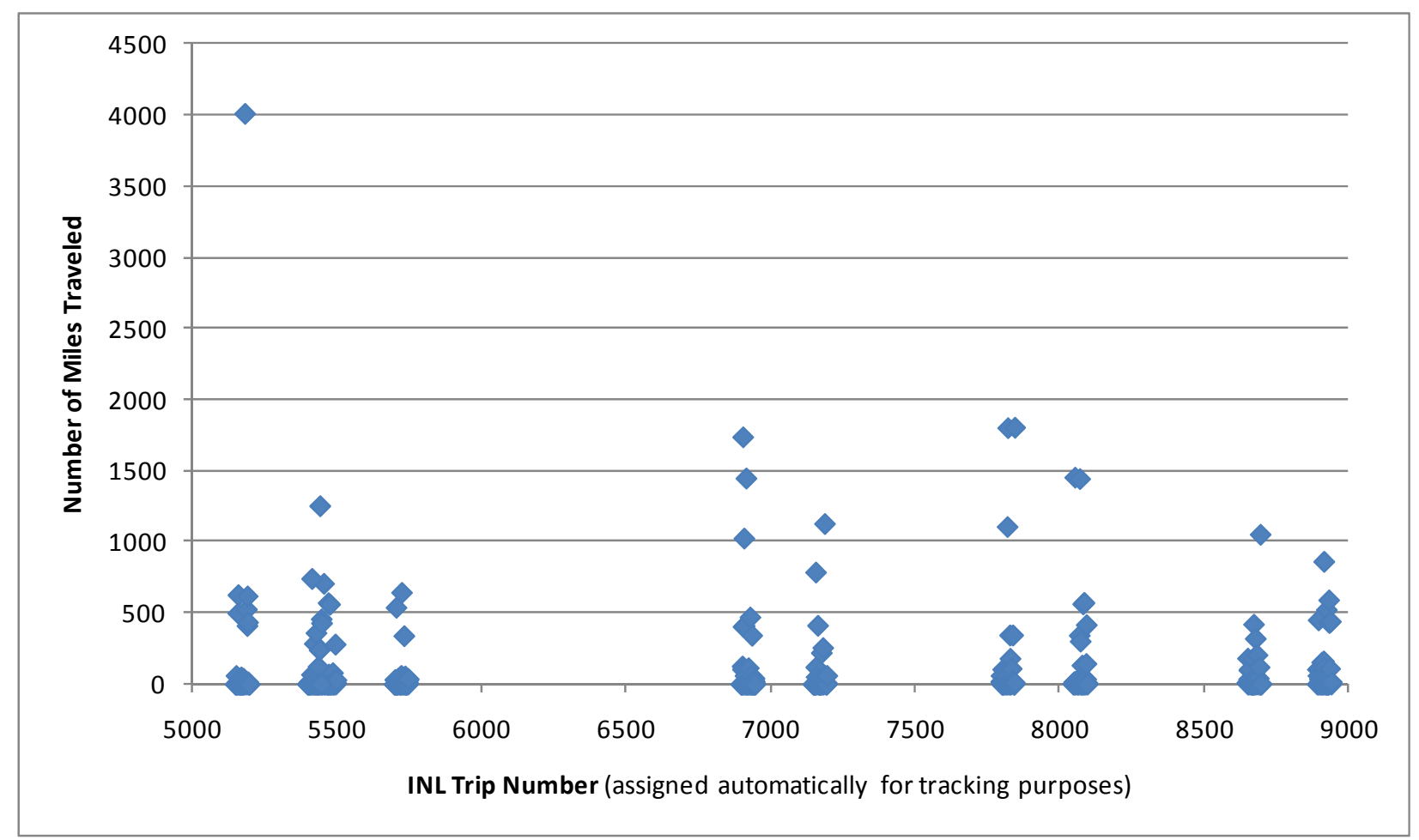

Figure 9. Number of miles traveled for sampled business travel in personally owned vehicles.

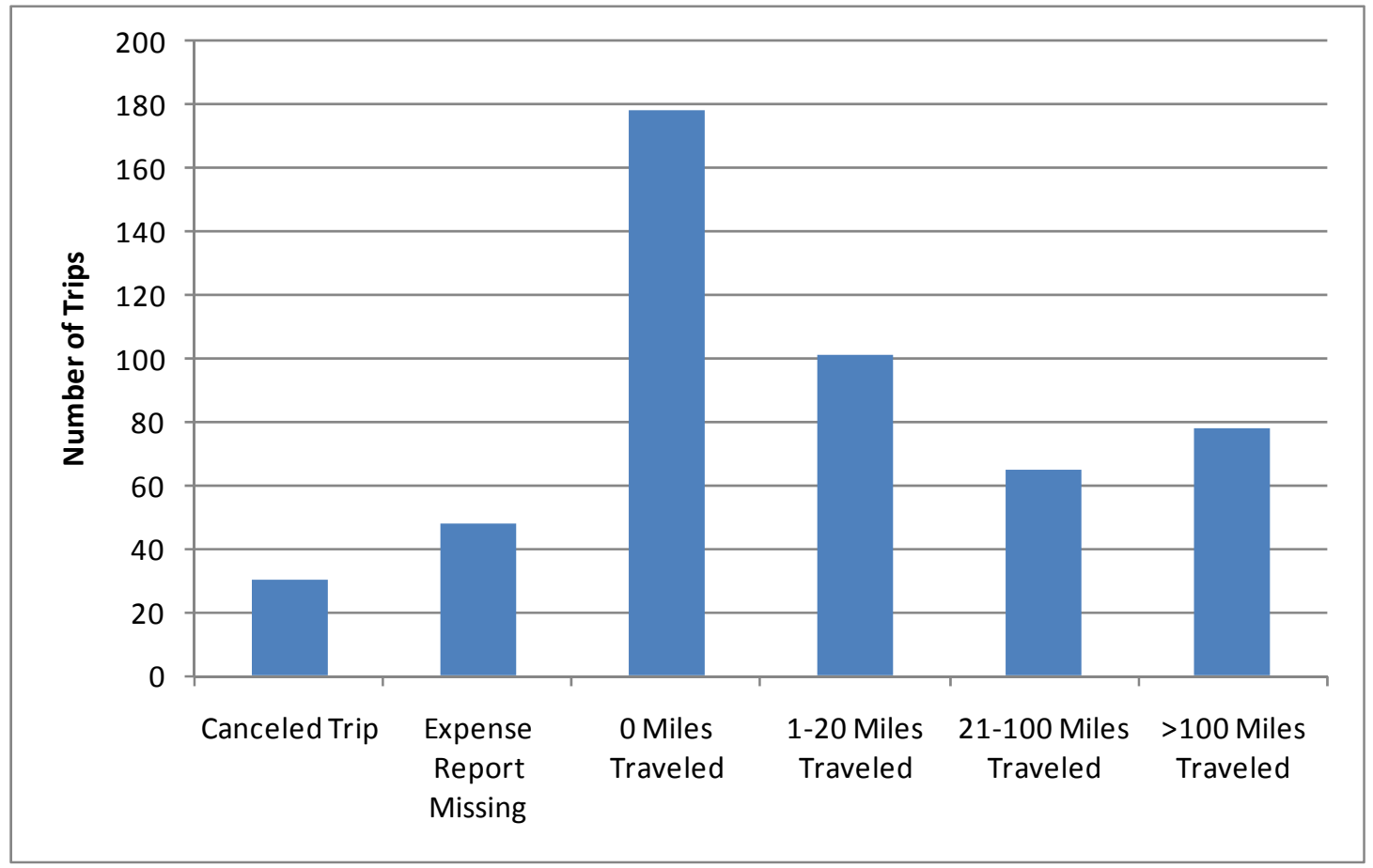

Figure 10. Miles traveled by number of trips in the sampled group.

To determine emission factors, it was conservatively assumed that $100 \%$ of the vehicle-miles were completed in light-duty trucks/vans/SUVs. 
Note that although submissions for travel requests during FY08 were completed electronically, the outcome of the trip, or how the employee actually traveled were not tracked in this system. This means that the only way to know the outcome of a particular trip, including whether it was canceled, is to review the paper or hard copy of the submitted expense report - a time-intensive task.

\subsubsection{Results Discussion}

The estimated 965,414.1 vehicle-miles that INL employees traveled during FY08 resulted in an estimated 515.85 MT CO 2 e. This equates to $2.8 \%$ of INL's Scope 3 emissions, and $0.5 \%$ of the total FY08 anthropogenic emissions considered.

This calculation is based on a representative sample, which is a reasonable method since gathering the actual numbers would be time intensive.

\subsubsection{Lessons Learned}

While reviewing the sampled expense reports, a number were identified as missing: a travel request form had been submitted, but there was no corresponding expense report submitted. Dick Schuman of the INL travel office identified a number of reasons that an expense report might be missing, and these include relocation, canceled trips, duplicate or rescheduled trip reports. The traveler may have chosen not to be reimbursed, or the traveler may not have incurred expenses and just needed insurance coverage (i.e., the employee traveled in a government vehicle [this would be counted in mobile combustion emissions as Scope 1], or rode with someone who was reimbursed). These reasons indicate that not all mileage traveled in personal vehicles for business travel could be tracked, even if all of the expense reports had been reviewed.

As of 2010, an electronic system has been introduced, which will allow for more streamlined and accurate tracking of personal car miles.

\subsubsection{Contracted MSW Disposal Emissions}

\subsubsection{Calculation Method}

To determine the Scope 3 emissions associated with INL's contracted offsite waste disposal from town facilities during FY08, the quantity of MSW sent to an offsite landfill was compiled. This information came from the City of Idaho Falls invoice records of the trash-collection history for each town facility, including dumpster location, size of dumpster, and pick-up frequency.

Since the City of Idaho Falls does not track actual volumes or weights of solid waste collected from INL facilities, the records of dumpster size and pick-up frequency from monthly invoices were used to calculate an estimated volume (assuming dumpster fill rates of $80 \%$ ). The FY08 volume of 12,274 cubic yards was converted to a weight based on an assumed solid waste density of 150 pounds per cubic yard (density value was selected based on EPA range [www.epa.gov/epawaste/conserve/tools/recmeas/docs/guide b.pdf]). This resulted in a weight of $1,841,040$ pounds or 920.5 tons for INL's offsite MSW disposal.

The TSD default methodology identifies the EPA's municipal solid waste mass balance model to calculate the GHG emissions associated with offsite MSW disposal. INL's FY08 mass of MSW disposed offsite was used with the calculation method in the TSD, along with default national averages (from the TSD).

\subsubsection{Results Discussion}

INL's offsite disposal of MSW during FY08 is estimated to contribute $11.87 \mathrm{MT} \mathrm{CO}_{2}$ e to their GHG inventory. This equates to $0.1 \%$ of INL's Scope 3 emissions, and a nearly negligible amount of the total FY08 anthropogenic emissions considered. 


\subsubsection{Lessons Learned}

Since the quantity of INL's MSW sent for offsite disposal is based on estimated volumes and an assumed density, it would be preferable to work with the City of Idaho Falls to get actual weights collected. If actual weights are not available, then actual volumes would be collected, and a sample of INL's MSW might be analyzed to determine an INL-specific density.

In addition, there are several small buildings located outside of Idaho Falls city limits that were not included in the amount of MSW collected from INL by contractors.

\subsubsection{Contracted Wastewater Treatment}

\subsubsection{Calculation Method}

Wastewater from INL's town facilities is sent for treatment to the City of Idaho Falls' wastewater treatment plant.

An employee count at INL's town facilities was provided by Human Resources as an average for FY08, based on the total number of employees at the end of each quarter. The reported figure was 1,799.5 employees. The number of visitors to the town facilities was estimated based on $5 \%$ of the number of employees. This yielded a total population of $1,889.5$, which was used with the calculation method in the TSD along with default national averages (from the TSD) for the specific treatment process.

\subsubsection{Results Discussion}

INL's contracted wastewater treatment during FY08 is estimated to contribute $56.38 \mathrm{MT} \mathrm{CO}_{2} \mathrm{e}$ emissions to the GHG inventory. This equates to $0.3 \%$ of INL's Scope 3 emissions, and a nearly negligible amount of the total FY08 anthropogenic emissions considered.

\subsubsection{Lessons Learned}

For future inventories it is believed that site-specific data and factors would produce more accurate results than calculations based on national averages. 


\section{PUTTING INL'S FOOTPRINT INTO PERSPECTIVE}

The INL GHG inventory indicates that during FY08, the Laboratory emitted 114,256 MT of anthropogenic $\mathrm{CO}_{2} \mathrm{e}$. This represents 29.2 MT for each employee working at INL that year.

The total GHG emissions generated by the Laboratory during FY08 are the equivalent to the $\mathrm{CO}_{2}$ emissions from any one of the following :

- Consuming 12.9 million gallons of gasoline or more than 265,000 barrels of oil

- Driving 21,846 passenger vehicles for a year

- Supplying electricity to 13,866 homes for a year.

h. Calculated with the EPA Greenhouse Gas Equivalencies in August 2010. 


\section{SUMMARY AND CONCLUSIONS}

Executive Order 13514 mandates reductions in the output of greenhouse gases generated by federal agencies. These reductions are targeted at $28 \%$ for direct (Scope 1 and 2) emissions, and $13 \%$ for indirect (Scope 3) emissions, all by 2020. The EO sets 2008 as the baseline year against which reductions will be measured, and this report documents INL's FY08 baseline emission calculations.

While preparing this inventory it was discovered that much of the data needed to quantify INL's GHG emissions already exist in high quality form, since it is recorded and tracked for reports to other federal entities. Some information is less accessible, but can be approximated from existing records and will be better tracked in the future due to the standards established by INL in response to the EO and the Laboratory's concern for the environment. Some must be estimated using national averages supplied in the Guidance.

During FY08 INL generated 114,256 MT of $\mathrm{CO}_{2}$ equivalents. Many factors influence INL's GHG emissions, including the large land area on which the Laboratory's facilities sit. The area requires long commutes, an extensive fleet to provide transportation for desert site workers, and it contains antiquated facilities, built before the current appreciation for energy efficiency and high-performance design. These factors tie directly into the following conclusions from INL's baseline GHG inventory:

- Electricity is the largest contributor to INL's GHG inventory, with over 50\% of the net anthropogenic $\mathrm{CO}_{2} \mathrm{e}$ emissions

- Other sources with high emissions were stationary combustion, fugitive emissions from the onsite landfill, mobile combustion (fleet fuels), and the employee commute

- Sources with low emissions were contracted waste disposal, wastewater treatment (onsite and contracted), and fugitive emissions from refrigerants.

INL's GHG inventory for FY08 was performed according the guidelines contained in unpublished draft documents currently under review. For this reason, some conclusions may be amended when the final guidance is published. INL recognizes its role as a DOE-sponsored research laboratory to "lead by example" in measuring, reporting, and reducing greenhouse gas emissions. To that end, the Laboratory has already moved to promote reductions in GHGs. Now that the baseline has been quantified, the next step is to identify a reduction strategy that focuses on particular activities. Future GHG inventories will determine the extent to which INL has successfully reached the ambitious targets set by Executive Order 13514. 


\section{REFERENCES}

74 FR 56260, "Final Rule: EPA Mandatory Reporting of Greenhouse Gases," Federal Register, Friday, October 30, 2009, See www.epa.gov/climatechange/emissions/downloads09/GHG-MRRFull\%20Version.pdf, Web page accessed August 2010.

ABC New/Technology, "Poll: Traffic in the United States, A Look Under the Hood of a Nation on Wheels," February 13, 2005, http://abcnews.go.com/Technology/Traffic/story?id=485098\&page=1, Web page accessed August 2010.

EPA, Appendix B, "Standard Volume-to-Weight Conversion Factors," Environmental Protection Agency, www.epa.gov/epawaste/conserve/tools/recmeas/docs/guide_b.pdf, Web page accessed August 2010.

EPA Climate Leaders, Commuting, Business Travel \& Mobile Transport, EPA 430-R-08-006, May 2008.

EPA Climate Leaders, Mobile Sources Guidance. www.epa.gov/stateply/documents/resources/mobilesource guidance.pdf, Web page accessed August 2010

EPA, eGRID2007 Version 1.1, Summary Tables, p. 6, 2005, www.epa.gov/cleanenergy/documents/egridzips/eGRID2007V1_1_year05_SummaryTables.pdf, Web page accessed August 2010.

Executive Order (EO) 13514, "Federal Leadership in Environmental, Energy, and Economic Performance," October 5, 2009.

Federal Greenhouse Gas Accounting and Reporting Guidance, Draft, July 2, 2010.

Federal Greenhouse Gas Accounting and Reporting Guidance: Technical Support Document, Draft, July 2, 2010.

FPL Energy Power Marketing, Inc. "Renewable Attestation Form," October 27, 2008. 


\section{Appendix A}

Global Warming Potentials 


\section{Appendix A \\ Global Warming Potentials}

Table A-1 below shows the GWPs for the GHGs that were considered to have been released by INL during FY08. All GWP values shown are based on those used in the EPA Mandatory Reporting Rule.

Table A-1. Global warming potentials.

\begin{tabular}{|l|r|l|c|}
\hline \multicolumn{1}{|c|}{ Name } & \multicolumn{1}{c|}{ Chemical formula } & $\begin{array}{c}\text { Global warming } \\
\text { potential } \\
\text { (100 year) }\end{array}$ \\
\hline Carbon dioxide & $124-38-9$ & $\mathrm{CO}_{2}$ & 1 \\
\hline Methane & $74-82-8$ & $\mathrm{CH}_{4}$ & 21 \\
\hline Nitrous oxide & $10024-97-2$ & $\mathrm{~N}_{2} \mathrm{O}$ & 310 \\
\hline HFC-23 & $75-46-7$ & $\mathrm{CHF}_{3}$ & 11,700 \\
\hline HFC-32 & $75-10-5$ & $\mathrm{CH}_{2} \mathrm{~F}_{2}$ & 650 \\
\hline HFC-125 & $354-33-6$ & $\mathrm{C}_{2} \mathrm{HF}_{5}$ & 2,800 \\
\hline HFC-134a & $811-97-2$ & $\mathrm{CH}_{2} \mathrm{FCF}_{3}$ & 1,300 \\
\hline HFC-143a & $420-46-2$ & $\mathrm{C}_{2} \mathrm{H}_{3} \mathrm{~F}_{3}$ & 3,800 \\
\hline HFC-152a & $75-37-6$ & $\mathrm{CH}_{3} \mathrm{CHF}_{2}$ & 140 \\
\hline HFC-365mfc & $406-58-6$ & $\mathrm{CH}_{3} \mathrm{CF}_{2} \mathrm{CH}_{2} \mathrm{CF}_{3}$ & 794 \\
\hline HFC-43-10mee & $138495-42-8$ & $\mathrm{CF}_{3} \mathrm{CFHCFHCF}_{2} \mathrm{CF}_{3}$ & 1,300 \\
\hline $\begin{array}{l}\text { PFC-116 } \\
\text { (Perfluoroethane) }\end{array}$ & $76-16-4$ & $\mathrm{C}_{2} \mathrm{~F}_{6}$ & 9,200 \\
\hline $\begin{array}{l}\text { Source: EPA Mandatory Reporting Rule, Federal Register, Friday, } \mathrm{October}_{3}, 2009 . \\
\text { Table A-1 to Subpart A of Part 98. See www.epa.gov/climatechange/emissions/downloads09/GHG-MRR- } \\
\text { Full\%20Version.pdf, Web page accessed August 2010. }\end{array}$ \\
\hline
\end{tabular}


Appendix B

\section{Emissions Factors Used}




\section{Appendix B}

\section{Emissions Factors Used}

\section{B-1. SCOPE ONE - DIRECT EMISSIONS}

Table B-1. Stationary combustion conversion and emissions factors used.

\begin{tabular}{|c|c|c|c|c|}
\hline $\begin{array}{l}\text { Emissions } \\
\text { Source }\end{array}$ & Factor Type & Amount & Units & Reference \\
\hline \multirow[t]{4}{*}{ Fuel Oil No. 2} & $\begin{array}{l}\text { HHV } \\
\text { Conversion } \\
\text { Factor }\end{array}$ & 0.138 & $\begin{array}{l}\text { MMBtu/ } \\
\text { gal }\end{array}$ & $\begin{array}{l}\text { EPA Mandatory Reporting Rule, } \\
\text { Federal Register, Friday, October } 30 \text {, } \\
\text { 2009, Table C-1 to Subpart C of Part } \\
\text { 98. }\end{array}$ \\
\hline & $\begin{array}{l}\mathrm{CO}_{2} \text { Emission } \\
\text { Factor }\end{array}$ & 73.96 & $\begin{array}{l}\mathrm{kg} \mathrm{CO}_{2} / \\
\mathrm{MMBtu}\end{array}$ & $\begin{array}{l}\text { EPA Mandatory Reporting Rule, } \\
\text { Federal Register, Friday, October } 30 \text {, } \\
\text { 2009, Table C-1 to Subpart C of Part } \\
98 .\end{array}$ \\
\hline & $\begin{array}{l}\mathrm{CH}_{4} \text { Emission } \\
\text { Factor }\end{array}$ & 0.003 & $\begin{array}{l}\mathrm{kg} \mathrm{CH}_{4} / \\
\text { MMBtu }\end{array}$ & $\begin{array}{l}\text { EPA Mandatory Reporting Rule, } \\
\text { Federal Register, Friday, October } 30 \text {, } \\
\text { 2009, Table C-2 to Subpart C of Part } \\
98 .\end{array}$ \\
\hline & $\begin{array}{l}\mathrm{N}_{2} \mathrm{O} \text { Emission } \\
\text { Factor }\end{array}$ & 0.0006 & $\begin{array}{l}\mathrm{kg} \mathrm{N}_{2} \mathrm{O} / \\
\mathrm{MMBtu}\end{array}$ & $\begin{array}{l}\text { EPA Mandatory Reporting Rule, } \\
\text { Federal Register, Friday, October } 30 \text {, } \\
\text { 2009, Table C-2 to Subpart C of Part } \\
98 .\end{array}$ \\
\hline \multirow[t]{4}{*}{$\begin{array}{l}\text { Liquefied } \\
\text { Natural Gas } \\
\text { (LNG) }\end{array}$} & $\begin{array}{l}\text { HHV } \\
\text { Conversion } \\
\text { Factor }\end{array}$ & 0.110 & $\begin{array}{l}\text { MMBtu/ } \\
\text { gal }\end{array}$ & $\begin{array}{l}\text { EPA Mandatory Reporting Rule, } \\
\text { Federal Register, Friday, October } 30 \text {, } \\
\text { 2009, Table C-1 to Subpart C of Part } \\
98 .\end{array}$ \\
\hline & $\begin{array}{l}\mathrm{CO}_{2} \text { Emission } \\
\text { Factor }\end{array}$ & 66.83 & $\begin{array}{l}\mathrm{kg} \mathrm{CO}_{2} / \\
\text { MMBtu }\end{array}$ & $\begin{array}{l}\text { EPA Mandatory Reporting Rule, } \\
\text { Federal Register, Friday, October } 30 \text {, } \\
\text { 2009, Table C-1 to Subpart C of Part } \\
98 .\end{array}$ \\
\hline & $\begin{array}{l}\mathrm{CH}_{4} \text { Emission } \\
\text { Factor }\end{array}$ & 0.001 & $\begin{array}{l}\mathrm{kg} \mathrm{CH}_{4} / \\
\mathrm{MMBtu}\end{array}$ & $\begin{array}{l}\text { EPA Mandatory Reporting Rule, } \\
\text { Federal Register, Friday, October } 30 \text {, } \\
\text { 2009, Table C-2 to Subpart C of Part } \\
98 .\end{array}$ \\
\hline & $\begin{array}{l}\mathrm{N}_{2} \mathrm{O} \text { Emission } \\
\text { Factor }\end{array}$ & 0.0001 & $\begin{array}{l}\mathrm{kg} \mathrm{N}_{2} \mathrm{O} / \\
\mathrm{MMBtu}\end{array}$ & $\begin{array}{l}\text { EPA Mandatory Reporting Rule, } \\
\text { Federal Register, Friday, October } 30 \text {, } \\
\text { 2009, Table C-2 to Subpart C of Part } \\
\text { 98. }\end{array}$ \\
\hline
\end{tabular}


Table B-1. (continued).

\begin{tabular}{|c|c|c|c|c|}
\hline $\begin{array}{l}\text { Emissions } \\
\text { Source }\end{array}$ & Factor Type & Amount & Units & Reference \\
\hline \multirow[t]{4}{*}{$\begin{array}{l}\text { Natural Gas } \\
\text { (Pipeline) }\end{array}$} & $\begin{array}{l}\text { Conversion } \\
\text { Factor }\end{array}$ & 0.10 & $\begin{array}{l}\text { MMBtu/ } \\
\text { therm }\end{array}$ & $\begin{array}{l}\text { Published conversion in common } \\
\text { literature }\end{array}$ \\
\hline & $\begin{array}{l}\mathrm{CO}_{2} \text { Emission } \\
\text { Factor }\end{array}$ & 53.02 & $\begin{array}{l}\mathrm{kg} \mathrm{CO}_{2} / \\
\text { MMBtu }\end{array}$ & $\begin{array}{l}\text { EPA Mandatory Reporting Rule, } \\
\text { Federal Register, Friday, October } 30 \text {, } \\
\text { 2009, Table C-1 to Subpart C of Part } \\
98 .\end{array}$ \\
\hline & $\begin{array}{l}\mathrm{CH}_{4} \text { Emission } \\
\text { Factor }\end{array}$ & 0.001 & $\begin{array}{l}\mathrm{kg} \mathrm{CH}_{4} / \\
\text { MMBtu }\end{array}$ & $\begin{array}{l}\text { EPA Mandatory Reporting Rule, } \\
\text { Federal Register, Friday, October } 30 \text {, } \\
\text { 2009, Table C-2 to Subpart C of Part } \\
\text { 98. }\end{array}$ \\
\hline & $\begin{array}{l}\mathrm{N}_{2} \mathrm{O} \text { Emission } \\
\text { Factor }\end{array}$ & 0.0001 & $\begin{array}{l}\mathrm{kg} \mathrm{N}_{2} \mathrm{O} / \\
\mathrm{MMBtu}\end{array}$ & $\begin{array}{l}\text { EPA Mandatory Reporting Rule, } \\
\text { Federal Register, Friday, October } 30 \text {, } \\
\text { 2009, Table C-2 to Subpart C of Part } \\
\text { 98. }\end{array}$ \\
\hline \multirow[t]{4}{*}{$\begin{array}{l}\text { Liquefied } \\
\text { Propane Gas } \\
(\text { LPG) }\end{array}$} & $\begin{array}{l}\text { HHV } \\
\text { Conversion } \\
\text { Factor }\end{array}$ & 0.092 & $\begin{array}{l}\text { MMBtu/ } \\
\text { gal }\end{array}$ & $\begin{array}{l}\text { EPA Mandatory Reporting Rule, } \\
\text { Federal Register, Friday, October } 30 \text {, } \\
\text { 2009, Table C-1 to Subpart C of Part } \\
\text { 98. }\end{array}$ \\
\hline & $\begin{array}{l}\mathrm{CO}_{2} \text { Emission } \\
\text { Factor }\end{array}$ & 62.98 & $\begin{array}{l}\mathrm{kg} \mathrm{CO}_{2} / \\
\mathrm{MMBtu}\end{array}$ & $\begin{array}{l}\text { EPA Mandatory Reporting Rule, } \\
\text { Federal Register, Friday, October } 30 \text {, } \\
\text { 2009, Table C-1 to Subpart C of Part } \\
98 .\end{array}$ \\
\hline & $\begin{array}{l}\mathrm{CH}_{4} \text { Emission } \\
\text { Factor }\end{array}$ & 0.003 & $\begin{array}{l}\mathrm{kg} \mathrm{CH}_{4} / \\
\text { MMBtu }\end{array}$ & $\begin{array}{l}\text { EPA Mandatory Reporting Rule, } \\
\text { Federal Register, Friday, October } 30 \text {, } \\
\text { 2009, Table C-2 to Subpart C of Part } \\
\text { 98. }\end{array}$ \\
\hline & $\begin{array}{l}\mathrm{N}_{2} \mathrm{O} \text { Emission } \\
\text { Factor }\end{array}$ & 0.0006 & $\begin{array}{l}\mathrm{kg} \mathrm{N}_{2} \mathrm{O} / \\
\mathrm{MMBtu}\end{array}$ & $\begin{array}{l}\text { EPA Mandatory Reporting Rule, } \\
\text { Federal Register, Friday, October } 30 \text {, } \\
\text { 2009, Table C-2 to Subpart C of Part } \\
98 .\end{array}$ \\
\hline
\end{tabular}


Table B-2. Mobile combustion emissions factors used.

\begin{tabular}{|c|c|c|c|c|}
\hline Emissions Source & Emission Type & Amount & Units & Reference \\
\hline \multirow[t]{2}{*}{$\begin{array}{l}\text { Gasoline } \\
\text { (Considered "Motor } \\
\text { gasoline") }\end{array}$} & $\begin{array}{l}\text { HHV Conversion } \\
\text { Factor }\end{array}$ & 0.125 & $\begin{array}{l}\text { MMBtu/ } \\
\text { gal }\end{array}$ & $\begin{array}{l}\text { EPA Mandatory Reporting Rule, } \\
\text { Federal Register, Friday, October } \\
\text { 30, 2009, Table C-1 to Subpart C } \\
\text { of Part 98. }\end{array}$ \\
\hline & $\begin{array}{l}\mathrm{CO}_{2} \text { Emissions } \\
\text { Factor }\end{array}$ & 70.22 & $\begin{array}{l}\mathrm{kg} \mathrm{CO}_{2} / \\
\text { MMBtu }\end{array}$ & $\begin{array}{l}\text { EPA Mandatory Reporting Rule, } \\
\text { Federal Register, Friday, October } \\
\text { 30, 2009, Table C-1 to Subpart C } \\
\text { of Part 98. }\end{array}$ \\
\hline \multirow{2}{*}{$\begin{array}{l}\text { Gasoline, Buses } \\
\text { (Considered "Gasoline } \\
\text { Buses") }\end{array}$} & $\begin{array}{l}\mathrm{CH}_{4} \text { Emissions } \\
\text { Factor }\end{array}$ & 0.021 & $\begin{array}{l}\mathrm{g} \mathrm{CH}_{4} / \\
\text { mile }\end{array}$ & $\begin{array}{l}\text { EPA Climate Leaders, Mobile } \\
\text { Sources Guidance }\end{array}$ \\
\hline & $\begin{array}{l}\mathrm{N}_{2} \mathrm{O} \text { Emissions } \\
\text { Factor }\end{array}$ & 0.017 & $\begin{array}{l}\mathrm{g} \mathrm{N}_{2} \mathrm{O} / \\
\text { mile }\end{array}$ & $\begin{array}{l}\text { EPA Climate Leaders, Mobile } \\
\text { Sources Guidance }\end{array}$ \\
\hline \multirow{2}{*}{$\begin{array}{l}\text { Gasoline, Light Duty } \\
\text { Car } \\
\text { (Considered “Gasoline } \\
\text { Passenger Car," Tier } 1 \\
\text { [1995-2000]) }\end{array}$} & $\begin{array}{l}\mathrm{CH}_{4} \text { Emissions } \\
\text { Factor }\end{array}$ & 0.0271 & $\begin{array}{l}\mathrm{g} \mathrm{CH}_{4} / \\
\text { mile }\end{array}$ & $\begin{array}{l}\text { EPA Climate Leaders, Mobile } \\
\text { Sources Guidance, Table A-1. }\end{array}$ \\
\hline & $\begin{array}{l}\mathrm{N}_{2} \mathrm{O} \text { Emissions } \\
\text { Factor }\end{array}$ & 0.0429 & $\begin{array}{l}\mathrm{g} \mathrm{N}_{2} \mathrm{O} / \\
\text { mile }\end{array}$ & $\begin{array}{l}\text { EPA Climate Leaders, Mobile } \\
\text { Sources Guidance, Table A-1. }\end{array}$ \\
\hline \multirow{2}{*}{$\begin{array}{l}\text { Gasoline, Light Duty } \\
\text { Trucks } \\
\text { (Considered “Gasoline } \\
\text { Light Duty Trucks," } \\
\text { Tier 1 [1995-2000]) }\end{array}$} & $\begin{array}{l}\mathrm{CH}_{4} \text { Emissions } \\
\text { Factor }\end{array}$ & 0.0452 & $\begin{array}{l}\mathrm{g} \mathrm{CH}_{4} / \\
\text { mile }\end{array}$ & $\begin{array}{l}\text { EPA Climate Leaders, Mobile } \\
\text { Sources Guidance, Table A- } 1 .\end{array}$ \\
\hline & $\begin{array}{l}\mathrm{N}_{2} \mathrm{O} \text { Emissions } \\
\text { Factor }\end{array}$ & 0.0871 & $\begin{array}{l}\mathrm{g} \mathrm{N}_{2} \mathrm{O} / \\
\text { mile }\end{array}$ & $\begin{array}{l}\text { EPA Climate Leaders, Mobile } \\
\text { Sources Guidance, Table A-1. }\end{array}$ \\
\hline \multirow{2}{*}{$\begin{array}{l}\text { Gasoline, Equipment } \\
\text { (Considered "Gasoline } \\
\text { Construction } \\
\text { Equipment") }\end{array}$} & $\begin{array}{l}\mathrm{CH}_{4} \text { Emissions } \\
\text { Factor }\end{array}$ & 0.5 & $\begin{array}{l}\mathrm{g} \mathrm{CH}_{4} / \\
\text { gal }\end{array}$ & $\begin{array}{l}\text { EPA Climate Leaders, Mobile } \\
\text { Sources Guidance, Table A- } 6 .\end{array}$ \\
\hline & $\begin{array}{l}\mathrm{N}_{2} \mathrm{O} \text { Emissions } \\
\text { Factor }\end{array}$ & 0.22 & $\begin{array}{l}\mathrm{g} \mathrm{N}_{2} \mathrm{O} / \\
\text { gal }\end{array}$ & $\begin{array}{l}\text { EPA Climate Leaders, Mobile } \\
\text { Sources Guidance, Table A- } 6 .\end{array}$ \\
\hline \multirow{2}{*}{$\begin{array}{l}\text { Gasoline, Truck } \\
\text { (Considered "Gasoline } \\
\text { Heavy Duty Trucks," } \\
\text { Tier 0) }\end{array}$} & $\begin{array}{l}\mathrm{CH}_{4} \text { Emissions } \\
\text { Factor }\end{array}$ & 0.0655 & $\begin{array}{l}\mathrm{g} \mathrm{CH}_{4} / \\
\text { mile } \\
\end{array}$ & $\begin{array}{l}\text { EPA Climate Leaders, Mobile } \\
\text { Sources Guidance, Table A-1. }\end{array}$ \\
\hline & $\begin{array}{l}\mathrm{N}_{2} \mathrm{O} \text { Emissions } \\
\text { Factor }\end{array}$ & 0.175 & $\begin{array}{l}\mathrm{g} \mathrm{N}_{2} \mathrm{O} / \\
\text { mile }\end{array}$ & $\begin{array}{l}\text { EPA Climate Leaders, Mobile } \\
\text { Sources Guidance, Table A-1. }\end{array}$ \\
\hline \multirow{2}{*}{$\begin{array}{l}\text { Liquefied Natural Gas } \\
\text { (LNG) and } \\
\text { Compressed Natural } \\
\text { Gas (CNG) } \\
\text { (Considered "Natural } \\
\text { Gasoline") }\end{array}$} & $\begin{array}{l}\text { HHV Conversion } \\
\text { Factor }\end{array}$ & 0.110 & $\begin{array}{l}\text { MMBtu/ } \\
\text { gal }\end{array}$ & $\begin{array}{l}\text { EPA Mandatory Reporting Rule, } \\
\text { Federal Register, Friday, October } \\
\text { 30, 2009, Table C-1 to Subpart C } \\
\text { of Part 98. }\end{array}$ \\
\hline & $\begin{array}{l}\mathrm{CO}_{2} \text { Emission } \\
\text { Factor }\end{array}$ & 66.83 & $\begin{array}{l}\mathrm{kg} \mathrm{CO}_{2} / \\
\mathrm{MMBtu}\end{array}$ & $\begin{array}{l}\text { EPA Mandatory Reporting Rule, } \\
\text { Federal Register, Friday, October } \\
\text { 30, 2009, Table C-1 to Subpart C } \\
\text { of Part } 98 \text {. }\end{array}$ \\
\hline \multirow{2}{*}{$\begin{array}{l}\text { CNG and LNG, Buses } \\
\text { (Considered "CNG } \\
\text { Buses") }\end{array}$} & $\begin{array}{l}\mathrm{CH}_{4} \text { Emissions } \\
\text { Factor }\end{array}$ & 1.966 & $\begin{array}{l}\mathrm{g} \mathrm{CH}_{4} / \\
\text { mile }\end{array}$ & $\begin{array}{l}\text { EPA Climate Leaders, Mobile } \\
\text { Sources Guidance, Table A-7. }\end{array}$ \\
\hline & $\begin{array}{l}\mathrm{N}_{2} \mathrm{O} \text { Emissions } \\
\text { Factor }\end{array}$ & 0.175 & $\begin{array}{l}\mathrm{g} \mathrm{N}_{2} \mathrm{O} / \\
\text { mile }\end{array}$ & $\begin{array}{l}\text { EPA Climate Leaders, Mobile } \\
\text { Sources Guidance, Table A- } 7 .\end{array}$ \\
\hline
\end{tabular}


Table B-2. (continued).

\begin{tabular}{|c|c|c|c|c|}
\hline Emissions Source & Emission Type & Amount & Units & Reference \\
\hline \multirow{2}{*}{$\begin{array}{l}\text { CNG, Light Duty Cars } \\
\text { and Trucks, and LNG, } \\
\text { Light Duty Trucks } \\
\text { (Considered "CNG } \\
\text { Light-duty Vehicles") }\end{array}$} & $\begin{array}{l}\mathrm{CH}_{4} \text { Emissions } \\
\text { Factor }\end{array}$ & 0.737 & $\begin{array}{l}\mathrm{g} \mathrm{CH}_{4} / \\
\text { mile }\end{array}$ & $\begin{array}{l}\text { EPA Climate Leaders, Mobile } \\
\text { Sources Guidance, Table A- } 7 .\end{array}$ \\
\hline & $\begin{array}{l}\mathrm{N}_{2} \mathrm{O} \text { Emissions } \\
\text { Factor }\end{array}$ & 0.05 & $\begin{array}{l}\mathrm{g} \mathrm{N}_{2} \mathrm{O} / \\
\text { mile }\end{array}$ & $\begin{array}{l}\text { EPA Climate Leaders, Mobile } \\
\text { Sources Guidance, Table A-7. }\end{array}$ \\
\hline \multirow[t]{2}{*}{$\begin{array}{l}\text { Diesel } \\
\text { (Considered “Distillate } \\
\text { Fuel Oil No. 2") }\end{array}$} & $\begin{array}{l}\text { HHV Conversion } \\
\text { Factor }\end{array}$ & 0.138 & $\begin{array}{l}\text { MMBtu/ } \\
\text { gal }\end{array}$ & $\begin{array}{l}\text { EPA Mandatory Reporting Rule, } \\
\text { Federal Register, Friday, October } \\
30,2009 \text {, Table C-1 to Subpart C } \\
\text { of Part } 98 \text {. }\end{array}$ \\
\hline & $\begin{array}{l}\mathrm{CO}_{2} \text { Emissions } \\
\text { Factor }\end{array}$ & 73.96 & $\begin{array}{l}\mathrm{kg} \mathrm{CO}_{2} / \\
\mathrm{MMBtu}\end{array}$ & $\begin{array}{l}\text { EPA Mandatory Reporting Rule, } \\
\text { Federal Register, Friday, October } \\
30,2009 \text {, Table C-1 to Subpart C } \\
\text { of Part } 98 \text {. }\end{array}$ \\
\hline \multirow{2}{*}{$\begin{array}{l}\text { Diesel, Buses } \\
\text { (Considered "Diesel } \\
\text { Heavy-Duty Trucks") }\end{array}$} & $\begin{array}{l}\mathrm{CH}_{4} \text { Emissions } \\
\text { Factor }\end{array}$ & 0.0051 & $\begin{array}{l}\mathrm{g} \mathrm{CH}_{4} / \\
\text { mile }\end{array}$ & $\begin{array}{l}\text { EPA Climate Leaders, Mobile } \\
\text { Sources Guidance, Table A- } 1 .\end{array}$ \\
\hline & $\begin{array}{l}\mathrm{N}_{2} \mathrm{O} \text { Emissions } \\
\text { Factor }\end{array}$ & 0.0048 & $\begin{array}{l}\mathrm{g} \mathrm{N}_{2} \mathrm{O} / \\
\text { mile }\end{array}$ & $\begin{array}{l}\text { EPA Climate Leaders, Mobile } \\
\text { Sources Guidance, Table A-1. }\end{array}$ \\
\hline \multirow{2}{*}{$\begin{array}{l}\text { Diesel, Light Duty } \\
\text { Trucks } \\
\text { (Considered “Diesel } \\
\text { Light Trucks," } \\
\text { Moderate) }\end{array}$} & $\begin{array}{l}\mathrm{CH}_{4} \text { Emissions } \\
\text { Factor }\end{array}$ & 0.0009 & $\begin{array}{l}\mathrm{g} \mathrm{CH}_{4} / \\
\text { mile }\end{array}$ & $\begin{array}{l}\text { EPA Climate Leaders, Mobile } \\
\text { Sources Guidance, Table A-1. }\end{array}$ \\
\hline & $\begin{array}{l}\mathrm{N}_{2} \mathrm{O} \text { Emissions } \\
\text { Factor }\end{array}$ & 0.0014 & $\begin{array}{l}\mathrm{g} \mathrm{N}_{2} \mathrm{O} / \\
\text { mile }\end{array}$ & $\begin{array}{l}\text { EPA Climate Leaders, Mobile } \\
\text { Sources Guidance, Table A-1. }\end{array}$ \\
\hline \multirow{2}{*}{$\begin{array}{l}\text { Diesel, Trucks } \\
\text { (Considered "Diesel } \\
\text { Heavy-duty Trucks") }\end{array}$} & $\begin{array}{l}\mathrm{CH}_{4} \text { Emissions } \\
\text { Factor }\end{array}$ & 0.0051 & $\begin{array}{l}\mathrm{g} \mathrm{CH}_{4} / \\
\text { mile }\end{array}$ & $\begin{array}{l}\text { EPA Climate Leaders, Mobile } \\
\text { Sources Guidance, Table A-1. }\end{array}$ \\
\hline & $\begin{array}{l}\mathrm{N}_{2} \mathrm{O} \text { Emissions } \\
\text { Factor }\end{array}$ & 0.0048 & $\begin{array}{l}\mathrm{g} \mathrm{N}_{2} \mathrm{O} / \\
\text { mile }\end{array}$ & $\begin{array}{l}\text { EPA Climate Leaders, Mobile } \\
\text { Sources Guidance, Table A-1. }\end{array}$ \\
\hline \multirow{2}{*}{$\begin{array}{l}\text { Diesel, Equipment } \\
\text { (Considered "Diesel } \\
\text { Construction } \\
\text { Equipment") }\end{array}$} & $\begin{array}{l}\mathrm{CH}_{4} \text { Emissions } \\
\text { Factor }\end{array}$ & 0.58 & $\begin{array}{l}\mathrm{g} \mathrm{CH}_{4} / \\
\text { gal }\end{array}$ & $\begin{array}{l}\text { EPA Climate Leaders, Mobile } \\
\text { Sources Guidance, Table A- } 6 .\end{array}$ \\
\hline & $\begin{array}{l}\mathrm{N}_{2} \mathrm{O} \text { Emissions } \\
\text { Factor }\end{array}$ & 0.26 & $\begin{array}{l}\mathrm{g} \mathrm{N}_{2} \mathrm{O} / \\
\text { gal }\end{array}$ & $\begin{array}{l}\text { EPA Climate Leaders, Mobile } \\
\text { Sources Guidance, Table A- } 6 .\end{array}$ \\
\hline \multirow[t]{2}{*}{ Propane } & $\begin{array}{l}\text { HHV Conversion } \\
\text { Factor }\end{array}$ & 0.091 & $\begin{array}{l}\text { MMBtu/ } \\
\text { gal }\end{array}$ & $\begin{array}{l}\text { EPA Mandatory Reporting Rule, } \\
\text { Federal Register, Friday, October } \\
30,2009 \text {, Table C-1 to Subpart C } \\
\text { of Part } 98 \text {. }\end{array}$ \\
\hline & $\begin{array}{l}\mathrm{CO}_{2} \text { Emissions } \\
\text { Factor }\end{array}$ & 61.46 & $\begin{array}{l}\mathrm{kg} \mathrm{CO}_{2} / \\
\mathrm{MMBtu}\end{array}$ & $\begin{array}{l}\text { EPA Mandatory Reporting Rule, } \\
\text { Federal Register, Friday, October } \\
30,2009 \text {, Table C-1 to Subpart C } \\
\text { of Part } 98 \text {. }\end{array}$ \\
\hline \multirow{2}{*}{$\begin{array}{l}\text { Propane, Equipment } \\
\text { (Considered "LPG } \\
\text { Heavy Duty } \\
\text { Vehicles") }\end{array}$} & $\begin{array}{l}\mathrm{CH}_{4} \text { Emissions } \\
\text { Factor }\end{array}$ & 0.066 & $\begin{array}{l}\mathrm{g} \mathrm{CH}_{4} / \\
\text { mile }\end{array}$ & $\begin{array}{l}\text { EPA Climate Leaders, Mobile } \\
\text { Sources Guidance, Table A-7. }\end{array}$ \\
\hline & $\begin{array}{l}\mathrm{N}_{2} \mathrm{O} \text { Emissions } \\
\text { Factor }\end{array}$ & 0.175 & $\begin{array}{l}\mathrm{g} \mathrm{N}_{2} \mathrm{O} / \\
\text { mile }\end{array}$ & $\begin{array}{l}\text { EPA Climate Leaders, Mobile } \\
\text { Sources Guidance, Table A-7. }\end{array}$ \\
\hline
\end{tabular}


Table B-2. (continued).

\begin{tabular}{|c|c|c|c|c|}
\hline Emissions Source & Emission Type & Amount & Units & Reference \\
\hline \multirow[t]{2}{*}{$\begin{array}{l}\text { Biodiesel } \\
\text { (Considered "Biodiesel } \\
[100 \%] ")\end{array}$} & $\begin{array}{l}\text { HHV Conversion } \\
\text { Factor }\end{array}$ & 0.128 & $\begin{array}{l}\text { MMBtu/ } \\
\text { gal }\end{array}$ & $\begin{array}{l}\text { EPA Mandatory Reporting Rule, } \\
\text { Federal Register, Friday, October } \\
30,2009 \text {, Table C-1 to Subpart C } \\
\text { of Part } 98 \text {. }\end{array}$ \\
\hline & $\begin{array}{l}\mathrm{CO}_{2} \text { Emissions } \\
\text { Factor }\end{array}$ & 73.84 & $\begin{array}{l}\mathrm{kg} \mathrm{CO}_{2} / \\
\mathrm{MMBtu}\end{array}$ & $\begin{array}{l}\text { EPA Mandatory Reporting Rule, } \\
\text { Federal Register, Friday, October } \\
30,2009 \text {, Table C-1 to Subpart C } \\
\text { of Part } 98 \text {. }\end{array}$ \\
\hline \multirow{2}{*}{$\begin{array}{l}\text { Biodiesel, Buses } \\
\text { (Considered "Diesel } \\
\text { Heavy-Duty Trucks") }\end{array}$} & $\begin{array}{l}\mathrm{CH}_{4} \text { Emissions } \\
\text { Factor }\end{array}$ & 0.0051 & $\begin{array}{l}\mathrm{g} \mathrm{CH}_{4} / \\
\text { mile } \\
\end{array}$ & $\begin{array}{l}\text { EPA Climate Leaders, Mobile } \\
\text { Sources Guidance, Table A- } 1 .\end{array}$ \\
\hline & $\begin{array}{l}\mathrm{N}_{2} \mathrm{O} \text { Emissions } \\
\text { Factor }\end{array}$ & 0.0048 & \begin{tabular}{|l|}
$\mathrm{g} \mathrm{N}_{2} \mathrm{O} /$ \\
mile \\
\end{tabular} & $\begin{array}{l}\text { EPA Climate Leaders, Mobile } \\
\text { Sources Guidance, Table A-1. }\end{array}$ \\
\hline \multirow{2}{*}{$\begin{array}{l}\text { Biodiesel, Light Duty } \\
\text { Trucks } \\
\text { (Considered "Diesel } \\
\text { Light Trucks," } \\
\text { Advanced) }\end{array}$} & $\begin{array}{l}\mathrm{CH}_{4} \text { Emissions } \\
\text { Factor }\end{array}$ & 0.0010 & $\begin{array}{l}\mathrm{g} \mathrm{CH}_{4} / \\
\text { mile }\end{array}$ & $\begin{array}{l}\text { EPA Climate Leaders, Mobile } \\
\text { Sources Guidance, Table A-1. }\end{array}$ \\
\hline & $\begin{array}{l}\mathrm{N}_{2} \mathrm{O} \text { Emissions } \\
\text { Factor }\end{array}$ & 0.0015 & $\begin{array}{l}\mathrm{g} \mathrm{N}_{2} \mathrm{O} / \\
\text { mile }\end{array}$ & $\begin{array}{l}\text { EPA Climate Leaders, Mobile } \\
\text { Sources Guidance, Table A-1. }\end{array}$ \\
\hline \multirow{2}{*}{$\begin{array}{l}\text { Biodiesel, Trucks } \\
\text { (Considered "Diesel } \\
\text { Heavy-Duty Trucks") }\end{array}$} & $\begin{array}{l}\mathrm{CH}_{4} \text { Emissions } \\
\text { Factor }\end{array}$ & 0.0051 & $\begin{array}{l}\mathrm{g} \mathrm{CH}_{4} / \\
\text { mile } \\
\end{array}$ & $\begin{array}{l}\text { EPA Climate Leaders, Mobile } \\
\text { Sources Guidance, Table A-1. }\end{array}$ \\
\hline & $\begin{array}{l}\mathrm{N}_{2} \mathrm{O} \text { Emissions } \\
\text { Factor }\end{array}$ & 0.0048 & $\begin{array}{l}\mathrm{g} \mathrm{N}_{2} \mathrm{O} / \\
\text { mile }\end{array}$ & $\begin{array}{l}\text { EPA Climate Leaders, Mobile } \\
\text { Sources Guidance, Table A-1. }\end{array}$ \\
\hline \multirow[t]{2}{*}{$\begin{array}{l}\text { Ethanol } \\
\text { (Considered "Ethanol } \\
[100 \%] ")\end{array}$} & $\begin{array}{l}\text { HHV Conversion } \\
\text { Factor }\end{array}$ & 0.084 & $\begin{array}{l}\text { MMBtu/ } \\
\text { gal }\end{array}$ & $\begin{array}{l}\text { EPA Mandatory Reporting Rule, } \\
\text { Federal Register, Friday, October } \\
30,2009 \text {, Table C-1 to Subpart C } \\
\text { of Part } 98 \text {. }\end{array}$ \\
\hline & $\begin{array}{l}\mathrm{CO}_{2} \text { Emissions } \\
\text { Factor }\end{array}$ & 68.44 & $\begin{array}{l}\mathrm{kg} \mathrm{CO}_{2} / \\
\mathrm{MMBtu}\end{array}$ & $\begin{array}{l}\text { EPA Mandatory Reporting Rule, } \\
\text { Federal Register, Friday, October } \\
30,2009 \text {, Table C-1 to Subpart C } \\
\text { of Part } 98 \text {. }\end{array}$ \\
\hline \multirow{2}{*}{$\begin{array}{l}\text { Ethanol, Light Duty } \\
\text { Cars and Trucks } \\
\text { (Considered "Ethanol } \\
\text { Light-duty Vehicles") }\end{array}$} & $\begin{array}{l}\mathrm{CH}_{4} \text { Emissions } \\
\text { Factor }\end{array}$ & 0.055 & $\begin{array}{l}\mathrm{g} \mathrm{CH}_{4} / \\
\text { mile }\end{array}$ & $\begin{array}{l}\text { EPA Climate Leaders, Mobile } \\
\text { Sources Guidance, Table A-7. }\end{array}$ \\
\hline & $\begin{array}{l}\mathrm{N}_{2} \mathrm{O} \text { Emissions } \\
\text { Factor }\end{array}$ & 0.067 & $\begin{array}{l}\mathrm{g} \mathrm{N}_{2} \mathrm{O} / \\
\text { mile } \\
\end{array}$ & $\begin{array}{l}\text { EPA Climate Leaders, Mobile } \\
\text { Sources Guidance, Table A-7. }\end{array}$ \\
\hline
\end{tabular}

Fugitive emissions are based directly on the GWP of the various gases emitted, so no additional table is provided from Table 7 that was shown previously in the main body. 


\section{B-2. SCOPE TWO - INDIRECT EMISSIONS}

Table B-3. Electricity emissions factors used.

\begin{tabular}{|c|c|c|c|c|}
\hline Emissions Source & Emission Type & Amount & Units & Reference \\
\hline \multirow{3}{*}{$\begin{array}{l}\text { INL Site Electricity } \\
\text { Purchase (and T\&D } \\
\text { loss) } \\
\text { (Considered "WECC } \\
\text { Northwest" eGRID } \\
\text { Subregion) }\end{array}$} & $\mathrm{CO}_{2}$ Emissions & 902.24 & $\begin{array}{l}\mathrm{lb} \mathrm{CO}_{2} / \\
\mathrm{MWh}\end{array}$ & $\begin{array}{l}\text { EPA, eGRID2007 Version } 1.1 \text { Year } \\
2005 \text { Summary Tables, p. 6, "Output } \\
\text { Emission Rates." }\end{array}$ \\
\hline & $\mathrm{CH}_{4}$ Emissions & 19.13 & $\begin{array}{l}\mathrm{lb} \mathrm{CH}_{4} / \\
\mathrm{GWh}\end{array}$ & $\begin{array}{l}\text { EPA, eGRID2007 Version 1.1 Year } \\
2005 \text { Summary Tables, p. 6, "Output } \\
\text { Emission Rates." }\end{array}$ \\
\hline & $\mathrm{N}_{2} \mathrm{O}$ Emissions & 14.90 & $\begin{array}{l}\mathrm{lb} \mathrm{N}_{2} \mathrm{O} / \\
\mathrm{GWh}\end{array}$ & $\begin{array}{l}\text { EPA, eGRID2007 Version 1.1 Year } \\
2005 \text { Summary Tables, p. } 6 \text {, "Output } \\
\text { Emission Rates." }\end{array}$ \\
\hline \multirow{3}{*}{$\begin{array}{l}\text { RECs Purchase } \\
\text { (Considered "ERCOT } \\
\text { All" eGRID } \\
\text { Subregion) }\end{array}$} & $\mathrm{CO}_{2}$ Emissions & $1,118.86$ & $\begin{array}{l}\mathrm{lb} \mathrm{CO}_{2} / \\
\mathrm{MWh}\end{array}$ & $\begin{array}{l}\text { EPA, eGRID2007 Version 1.1 Year } \\
2005 \text { Summary Tables, p. 6, "Non- } \\
\text { baseload Output Emission Rates." }\end{array}$ \\
\hline & $\mathrm{CH}_{4}$ Emissions & 20.15 & $\begin{array}{l}\mathrm{lb} \mathrm{CH}_{4} / \\
\mathrm{GWh}\end{array}$ & $\begin{array}{l}\text { EPA, eGRID2007 Version 1.1 Year } \\
2005 \text { Summary Tables, p. 6, "Non- } \\
\text { baseload Output Emission Rates." }\end{array}$ \\
\hline & $\mathrm{N}_{2} \mathrm{O}$ Emissions & 5.68 & $\begin{array}{l}\mathrm{lb} \mathrm{N}_{2} \mathrm{O} / \\
\mathrm{GWh}\end{array}$ & $\begin{array}{l}\text { EPA, eGRID2007 Version } 1.1 \text { Year } \\
2005 \text { Summary Tables, p. 6, "Non- } \\
\text { baseload Output Emission Rates." }\end{array}$ \\
\hline
\end{tabular}




\section{B-3. SCOPE THREE - INDIRECT EMISSIONS}

Table B-4. Employee commute, rental car miles, and personal car miles emissions factors used.

\begin{tabular}{|c|c|c|c|c|}
\hline Emissions Source & Emission Type & Amount & Units & Reference \\
\hline \multirow[t]{3}{*}{ Passenger Cars } & $\mathrm{CO}_{2}$ Emissions & 0.364 & $\begin{array}{l}\mathrm{kg} \mathrm{CO}_{2} / \\
\text { vehicle- } \\
\text { mile }\end{array}$ & $\begin{array}{l}\text { Table 5, EPA Climate Leaders } \\
\text { Commuting, Business Travel \& } \\
\text { Mobile Transport, EPA 430-R- } \\
\text { 08-006, May 2008. }\end{array}$ \\
\hline & $\mathrm{CH}_{4}$ Emissions & $\begin{array}{l}0.031 \mathrm{x} \\
10^{-3}\end{array}$ & $\begin{array}{l}\mathrm{kg} \mathrm{CH}_{4} / \\
\text { vehicle- } \\
\text { mile }\end{array}$ & $\begin{array}{l}\text { Table 5, EPA Climate Leaders } \\
\text { Commuting, Business Travel \& } \\
\text { Mobile Transport, EPA 430-R- } \\
\text { 08-006, May 2008. }\end{array}$ \\
\hline & $\mathrm{N}_{2} \mathrm{O}$ Emissions & $\begin{array}{l}0.032 \mathrm{x} \\
10^{-3}\end{array}$ & $\begin{array}{l}\mathrm{kg} \mathrm{N}_{2} \mathrm{O} / \\
\text { vehicle- } \\
\text { mile }\end{array}$ & $\begin{array}{l}\text { Table 5, EPA Climate Leaders } \\
\text { Commuting, Business Travel \& } \\
\text { Mobile Transport, EPA 430-R- } \\
\text { 08-006, May 2008. }\end{array}$ \\
\hline \multirow[t]{3}{*}{$\begin{array}{l}\text { Light-duty } \\
\text { truck/van/SUV }\end{array}$} & $\mathrm{CO}_{2}$ Emissions & 0.519 & $\begin{array}{l}\mathrm{kg} \mathrm{CO}_{2} / \\
\text { vehicle- } \\
\text { mile }\end{array}$ & $\begin{array}{l}\text { Table 5, EPA Climate Leaders } \\
\text { Commuting, Business Travel \& } \\
\text { Mobile Transport, EPA 430-R- } \\
\text { 08-006, May 2008. }\end{array}$ \\
\hline & $\mathrm{CH}_{4}$ Emissions & $\begin{array}{l}0.036 \times \\
10^{-3}\end{array}$ & $\begin{array}{l}\mathrm{kg} \mathrm{CH} / \\
\text { vehicle- } \\
\text { mile }\end{array}$ & $\begin{array}{l}\text { Table 5, EPA Climate Leaders } \\
\text { Commuting, Business Travel \& } \\
\text { Mobile Transport, EPA 430-R- } \\
08-006 \text {, May 2008. }\end{array}$ \\
\hline & $\mathrm{N}_{2} \mathrm{O}$ Emissions & $\begin{array}{l}0.047 \mathrm{x} \\
10^{-3}\end{array}$ & $\begin{array}{l}\mathrm{kg} \mathrm{N}_{2} \mathrm{O} / \\
\text { vehicle- } \\
\text { mile }\end{array}$ & $\begin{array}{l}\text { Table 5, EPA Climate Leaders } \\
\text { Commuting, Business Travel \& } \\
\text { Mobile Transport, EPA 430-R- } \\
\text { 08-006, May 2008. }\end{array}$ \\
\hline
\end{tabular}

Table B-5. Business travel airline miles emissions factors used.

\begin{tabular}{|c|c|c|c|c|}
\hline Emissions Source & Emission Type & Amount & Units & Reference \\
\hline \multirow[t]{3}{*}{$\begin{array}{l}\text { Airline Miles } \\
\text { (Considered } \\
\text { "Distance Not } \\
\text { Known") }\end{array}$} & $\mathrm{CO}_{2}$ Emissions & 0.271 & $\begin{array}{l}\mathrm{kg} \mathrm{CO}_{2} / \\
\text { passenger- } \\
\text { mile }\end{array}$ & $\begin{array}{l}\text { Table 4, EPA Climate Leaders, } \\
\text { Commuting, Business Travel \& } \\
\text { Mobile Transport, EPA 430-R- } \\
\text { 08-006, May 2008. }\end{array}$ \\
\hline & $\mathrm{CH}_{4}$ Emissions & 0.0104 & $\begin{array}{l}\mathrm{g} \mathrm{CH}_{4} / \\
\text { passenger- } \\
\text { mile }\end{array}$ & $\begin{array}{l}\text { Table 4, EPA Climate Leaders, } \\
\text { Commuting, Business Travel \& } \\
\text { Mobile Transport, EPA 430-R- } \\
\text { 08-006, May } 2008 .\end{array}$ \\
\hline & $\mathrm{N}_{2} \mathrm{O}$ Emissions & 0.0085 & $\begin{array}{l}\mathrm{g} \mathrm{N}_{2} \mathrm{O} / \\
\text { passenger- } \\
\text { mile }\end{array}$ & $\begin{array}{l}\text { Table 4, EPA Climate Leaders, } \\
\text { Commuting, Business Travel \& } \\
\text { Mobile Transport, EPA 430-R- } \\
\text { 08-006, May } 2008 .\end{array}$ \\
\hline
\end{tabular}


Appendix C

Sample Calculation 


\section{Appendix C}

\section{Sample Calculation}

This calculation for electricity is an example of the calculation steps followed for calculating the GHG emissions from each of INL's emissions categories:

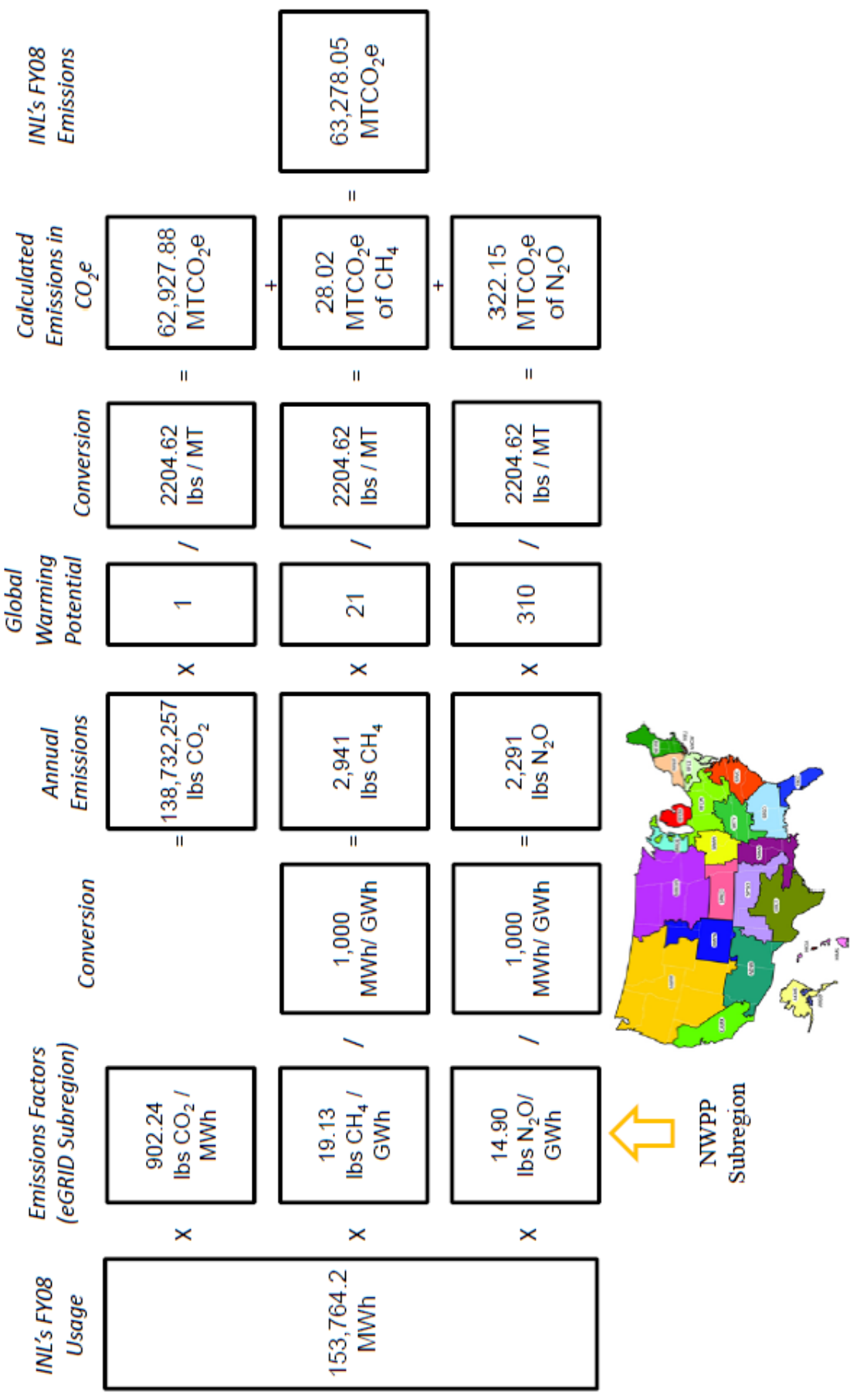


Attachment 1

\section{Receipt for RECs Purchased in FY08}




\section{Attachment 1}

\section{Receipt for RECs Purchased in FY08}

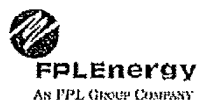

\section{FPL ENERGY POWER MARKETING, INC. RENEWABLE ATTESTATION FORM}

\section{Facility information}

Name of Generation Facility ( $\left({ }^{\prime} F a c i l i t y "\right)$ ): Capricorn Ridge Wind, LLC

Company or Person that Owns Facility ("Seller"): FPL Energy Power Marketing, Inc.

Address of Facility: 533 Bird Lane

$$
\text { Sterling TX, } 76952
$$

North American Electricity Reliabilty Corporation (NERC) region in which Facility is located':

Facility ID Number: 555998 EIA G QF 2 circle one) Nameplate Capacily (MW): $166 \mathrm{MW}$

Date Facility was First Operational: $11 / 07$ Date of Capacily Upgrade or Repowering ${ }^{3}$ :_L

Contact Person: John Mantyh

Title: Regional Director

Telephone: $561-304-6150$

Email Address: john_mantyh@fpl.com

11. Renewable Electricity or RECs ${ }^{4}$ supplied to Purchaser indicated below, by fuel type

List the renewable MWhs generated in each quarter and sold or transferred to purchaser identified below as a separate line item.

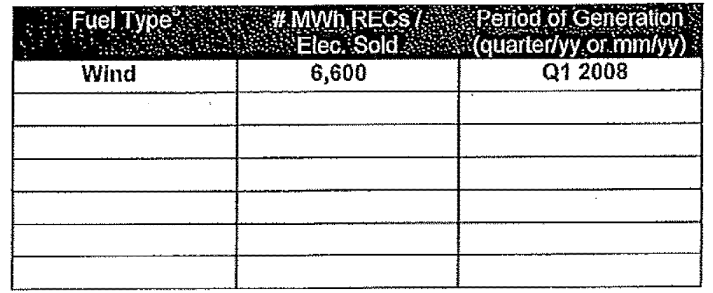

\footnotetext{
${ }^{1}$ If you are unsure of which region Facility is in, see http: $/$ www. nerc.com/regionall

${ }^{2}$ Enter Energy Information Administration (EIA) identification number for the generating faclity; If no EIA number, enter the utility-assigned Qualifying Facility (QF) identification number.

${ }^{3}$ If applicable. Repowered facilities must meet Green-e's criteria for repowering, available at hitp://www.greene.org/docs/Repowering Defin and Instructions.doc

${ }^{4}$ Renewable Energy Certificates, which represent the renewable attributes of 1 MWh of renewable electricity

generation.
If using biomass fuels, list out the specific type (i.e. landill gas, wood waste, etc.) and fill in section IV below.
} 


\section{Declaration}

I, (print name and title) Charles S. Schultz declare that the (indicate

with " $x$ ") __ electricity bundled with renewable attributes / $\mathrm{x}$ renewable attributes only ${ }^{6}$ listed above were sold exclusively from Selter to Defense Energy Support Center.

("Purchaser").

I further declare that:

1) all the renewable attributes (including $\mathrm{CO}_{2}$ benefits), including any emissions offsets, reductions or claims, represented by the renewable electricity generation listed above were transferred to Purchaser;

2) to the best of my knowledge, the renewable attributes were not sold, marketed or otherwise claimed by a third party other than Purchaser;

3) Seller sold the renewable attributes only once;

4) the renewable attributes or the electricily that was generated with the attributes was not used to meet any federal, state or local renewable energy requirement, tenewable energy procurement, renewable porffolio standard, or other renewable energy mandate by Seller, nor to the best of my knowledge, by any other entity other than Purchaser: ${ }^{7}$

5) the renewable electricity sold or electricity associated with the attributes sold was not used on-site for powering electric generation equipment (parasitic load);

6) if Purchaser is receiving electricty bundled with renewable attributes from Seller, the renewable electricity was delivered into the NERC region in which Facility is located;

7) if Facility is located in Canada, it is EcoLogo certified and was throughout the Period of Generation; and

8) the electricily that was generated with the altributes was not separately sold, separately marketed or otherwise separately represented as renewable energy by Seller, or, to the best of my knowledge, any other entity other than Purchaser.

Please indicate the following:

Is Facility owner reporting its direct greenhouse gas emissions in a legally binding cap and trade program for the time period of generation listed on this form?

r Yes: ${ }^{8}$ list the cap and trade program:

* No

If Seller is providing only RECs to Purchaser and selling the associated electricity to a utility or foad-serving entity, please write the name of the utility or load-serving entity here:

a Check box if sale is part of a Qualifying Facility (OF) Facility

\footnotetext{
${ }^{5}$ If selling renewable attributes to Purchaser without electricty, please fill in the name of the load serving entity buying the undifferentiated electricity, if applicable at the bottom of this page.

${ }^{7}$ Renewable attributes used by Purchaser for any of the purposes listed in 4) are ineligible for Green-e certification.

an this case the renewable energy or RECs reported on this form may be ineligible for Green-e certification. For more information, contact Green-e Staff at 415-561-2100.
} 


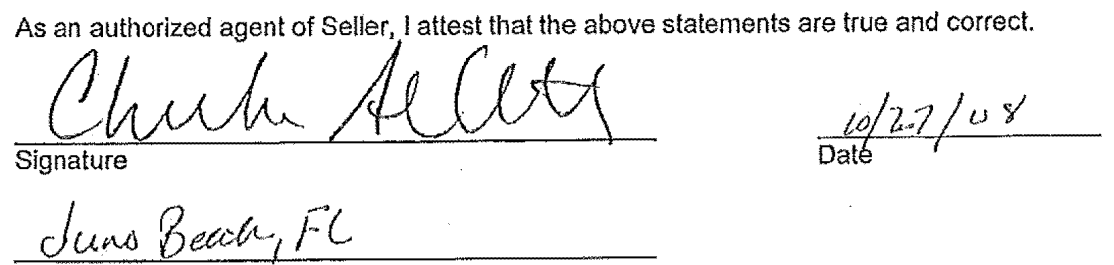

Place of Execution

This Form is used by the Center for Resource Solutions to verify the accuracy of claims made by retail marketers. The information on this form is held strictly confidential and will not be shared with any other party except in aggregate form. 